Bryn Mawr College

Scholarship, Research, and Creative Work at Bryn Mawr College

Classical and Near Eastern Archaeology Faculty

Research and Scholarship

Classical and Near Eastern Archaeology

1998

\title{
An Issue of Methodology: Anakreon, Perikles, Xanthippos
}

Brunilde S. Ridgway

Bryn Mawr College, bridgway@brynmawr.edu

Let us know how access to this document benefits you.

Follow this and additional works at: http://repository.brynmawr.edu/arch_pubs

Part of the Classical Archaeology and Art History Commons, and the History of Art, Architecture, and Archaeology Commons

\section{Custom Citation}

Ridgway, Brunilde S. 1998. An Issue of Methodology: Anakreon, Perikles, Xanthippos. American Journal of Archaeology 102:717-738.

This paper is posted at Scholarship, Research, and Creative Work at Bryn Mawr College. http://repository.brynmawr.edu/arch_pubs/7

For more information, please contact repository@brynmawr.edu. 


\title{
An Issue of Methodology: Anakreon, Perikles, Xanthippos
}

\author{
BRUNILDE SISMONDO RIDGWAY
}

\begin{abstract}
Standard assumptions about the portrait of Anakreon known through works of the Roman period are here reviewed in light of all available evidence. Pausanias's mention of a statue of the Ionic poet on the Athenian Akropolis has led to extensive conjectures about Anakreon's relationship to Perikles' family and the message such a monument was meant to convey. The possibility is raised that the known portrait was created later than ca. 440 , and, more specifically, that the full-body representation now in Copenhagen served the requirements
\end{abstract}

\footnotetext{
* I would like to thank Mette Moltesen of the Ny Carls. berg Glyptotek and Despoina Tsiafakis of the J. Paul Getty Museum for their courtesy in providing me with photographs of the pieces in their collections. I am indebted to Dr. Moltesen and Pia Guldager Bilde of Aarhus University for discussing the Copenhagen pieces with me, both in the $\mathrm{Ny}$ Carlsberg Glyptotek and by letter. I am very grateful to Richard Hamilton, who has kindly read and commented on the philological part of a draft of this article and has provided much helpful bibliography. One anonymous $A J A$ reviewer has saved me from an embarrassing mistake. All dates are B.C. unless otherwise specified. My article had been fully written and submitted when Fred Kleiner alerted me to the announcement of a new book by Krumeich (1997), which I was later able to read. Krumeich makes many of the same points I made. I have now added reference to the relevant passages, pleased to see that another scholar has reached some of the same conclusions.

The following abbreviations are used throughout: Bowra 1961

C.M. Bowra, Greek Lyric Poetry ${ }^{2}$ (Oxford 1961).

Campbell 1988 D.A. Campbell, Greek Lyric II (Loeb Classical Library, Cambridge, Mass. 1988).

Dörig 1977

J. Dörig, Onatas of Aegina (Monumenta graeca et romana 1, Leiden 1977).

Fuchs 1995

W. Fuchs, "In Search of Herodotus' Poseidon at the Isthmos," Thetis 2 (1995) 73-78.

Hölscher 1975 T. Hölscher, "Die Aufstellung des Perikles-Bildnisses und ihre Bedeutung," WürzJbb n.s. 1 (1975) 187-218.

Johansen 1992 F. Johansen, Catalogue. Greek Portraits. Ny Carlsberg Glyptotek (Copenhagen 1992).

Krumeich 1997 R. Krumeich, Bildnisse griechischer Herr. scher und Staatsmänner im 5. Jahrhundert v. Chr. (Munich 1997).

Neudecker 1988 R. Neudecker, Die Skulpturenausstattung römischer Villen in Italien (Mainz 1988).

POG 1965

G.M.A. Richter, The Portraits of the Greeks 1 (London 1965).
}

of its Roman commissioner rather than reproducing a true fifth-century original.*

A recent article by Emmanuel Voutiras ${ }^{1}$ convincingly argues against one of the most generally accepted tenets of Greek portraiture: it reverses the traditional sequence of Sokrates' portraits, claiming the precedence of Type B over Type A and undermining both its chronology and its standard attribution to Lysippos. ${ }^{2}$ In so doing, the author also re-

Poulsen 1931

F. Poulsen, "Iconographic Studies in the Ny Carlsberg Glyptothek I. Anacreon," in From the Collection of the Ny Carlsberg Glyptotek 1 (Copenhagen 1931) 1-15.

Price 1990 S.D. Price, "Anacreontic Vases Reconsidered," GRBS 31 (1990) 133-75.

Ridgway $1984 \quad$ B.S. Ridgway, Roman Copies of Greek Sculp. ture: The Problem of the Originals (Ann Arbor 1984).

Rosenmeyer P.A. Rosenmeyer, The Poetics of Imitation. 1992 Anacreon and the Anacreontic Tradition (Cambridge 1992).

Schefold 1997 K. Schefold, Die Bildnisse der antiken Dichter, Redner und Denker ${ }^{2}$ (revised and enlarged; Basel 1997).

Türr 1971 K.M. Türr, Eine Musengruppe hadrianischer Zeit. Die sogennanten Thespiaden (Berlin 1971).

Zanker 1995 P. Zanker, The Mask of Socrates. The Image of the Intellectual in Antiquity (Sather Classical Lectures 59; Berkeley 1995).

${ }^{1}$ E. Voutiras, "Sokrates in der Akademie: Die früheste bezeugte Philosophenstatue," AM 109 (1994) 133-61. According to him, Type $A$ is a manneristic derivation from Type B, which in turn copies a statue made, on the authority of Philodemos of Gadara (papyrus 1021) and his sources, by an otherwise unknown sculptor Butes. The anecdotal attribution of a portrait of Sokrates to Lysippos probably stemmed from the later desire to associate it with a famous master (146 n. 59). The image was set up as a private dedication to the Muses by Plato and his followers on the grounds of the Academy shortly after its founding in 387.

${ }^{2}$ For the traditional position, see $P O G$ 1965, 109-19; Schefold 1997, 126-29 figs. 52a-b (Type A) and 174-77 figs. 82-83 (Type B) with commentary and bibliography on 494-95 and 503-504, respectively. I had accepted the standard interpretation in Greek Sculpture in the Art Museum, Princeton University (Princeton 1994) 64-67, no. 19 (q.v. for additional references), but cf. my more skeptical position in Fourth Century Styles in Greek Sculpture (Madison 1997) 186-87 n. 33. 
minds us that even the most widely established theories should be subject to periodic revision, in the light of new acquisitions or greater understand. ing of ancient practices, especially with regard to the role of the so-called Roman copies in the difficult field of classical portraiture. Although my comments and queries may not lead to a similarly plausible conclusion, I wish to raise here the issues connected with another ancient image that has puzzled me for some time: that of the poet Anakreon.

During his visit to the Athenian Akropolis, Pausanias (1.25.1) saw a portrait of Xanthippos, father of Perikles, near ( $\pi \lambda \eta \sigma i o v)$ one of Anakreon, in the general area of the Parthenon. Perikles too, the periegete stated, had his image on the citadel, but else.

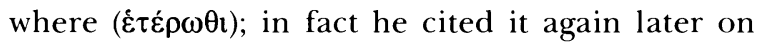
(1.28.2), close to the Propylaia, next to the Athena Lemnia by Pheidias. Pausanias's wording has been noted, and the location of Perikles' statue, not together with his father but near a dedication by Athenian klerouchs, has been considered indicative of the statesman's desire to avoid dynastic implications and symbolic of his expansionistic policy. Other inferences seem less convincing. The proximity of the Anakreon and the Xanthippos has been taken to sug. gest that the two men were friends, and one scholar has even visualized the sculptures as a group - the Athenian listening to the poet singing. Because Pliny (HN 34.74) mentioned that Kresilas made a statue of "Olympian Perikles," the Cretan sculptor has been credited with the Akropolis image (although Pausanias does not name its master), and therefore, by extension, with those of the statesman's father and his "neighbor." Conversely, these latter have been given to Pheidias, on grounds of that master's relationship

\footnotetext{
${ }^{3}$ On the meaningful location of the Perikles, see Hölscher 1975, 192-93. For the thematic grouping of Anakreon and Xanthippos (one singing, the other listening), see J. Frel, Greek Portraits in the J. Paul Getty Museum (Malibu 1981) 39. See also infra n. 4 for discussion connected with specific attributions of extant replicas.

${ }^{4}$ On Perikles' portraiture: $P O G$ 1965, 102-104; no new evidence is adduced in the abridged and revised edition of $P O G$ by R.R.R. Smith (Ithaca 1984) 173-75. Further dis. cussion and bibliography are in the Princeton catalogue, Ridgway 1994 (supra n. 2) 40-44, no. 11 (J.C. Griffin)-a fragmentary head is not accepted as a true replica. See also Schefold 1997, 101-102 fig. 33 and commentary on 490. A thorough discussion of Perikles' life and possible portraits appears now in Krumeich 1997, 114-25, 236-39, cat. nos. A 33-41, with healthy skepticism about attribution to Kresilas of the inscribed portrait type: pp. 115-18.

Anakreon: $P O G$ 1965, 75-78, with listing of all replicas and citation of relevant ancient sources; Richter/Smith 1984 (supra) 83-86; Schefold 1997, 102-103 fig. 34, with commentary on 491 . For the statue in Copenhagen, see now
}

with Perikles via the Parthenon, and on the assumption that Perikles himself commissioned the dedications. Other sculptors (Kolotes, Pythagoras) have also been proposed for the Anakreon, on uncertain grounds. ${ }^{3}$

On the basis of Pausanias and Pliny, identifications of extant Roman "copies" have also been attempted. Perikles' portrait is attested through two inscribed herm busts and two heads that seem to copy the same helmeted prototype; nothing ensures, however, that they reproduce Kresilas's statue, since Pliny does not describe it and Plutarch (Per. 3.2) comments that almost all artists portrayed the strategos in military headgear, thus implying that many other images of him existed. Anakreon's identification also is based on an inscribed herm. A full-statue replica now in Copenhagen, which shows him standing and wearing only a chlaina, and seven additional heads depict the same type; two more herms carry the poet's name but are headless. It has been assumed that the original was the Akropolis statue seen by Pausanias, although the periegete states only that Anakreon appeared to be singing while drunk. Portraits of the poet mentioned by other ancient sources (one presumably on Teos, his birthplace: Theoc. Anth. Lyr. Graec. 9.599) are described as wearing different items of clothing, and Tean coins attest to at least one seated image. Finally, Xanthippos presents a more difficult problem, because stylistic grounds only can be adduced in support of each proposal. A presumed resemblance to the Anakreon has been argued for a helmeted head in Berlin of which a battered replica is now in the J. Paul Getty Museum, but the case is far from convincing; other suggestions are equally unprovable. $^{4}$

Johansen 1992, 18-21, no. 1 (I.N. 491; with full bibliography; other references shall be given infra); Schefold 1997, 270-71 fig. 151 with commentary on 522. Nos. 2 and 3 (I.N. 2001, pp. 22-23, and I.N. 2590, pp. 24-25, respectively) in Johansen 1992 have been at times identified as Xanthippos, but also as many other notables, without agreement. For the head in Malibu and the one in Berlin, see Frel (supra n. 3) 38-39, no. 1, with discussion on 14-15 (cf. fig. 36, Anakreon, and fig. 38, Berlin head). Richter, $P O G$ 1965, 101 mentions some attributions but finds none of them con. vincing. G. Hafner, "Anakreon und Xanthippos," JdI 71 (1956) 1-28 wants to recognize both individuals on the shield of the Athena Parthenos: Anakreon would be the so-called Kapaneos (because of its resemblance to the inscribed herm), and Xanthippos the warrior wearing a pilos. Schefold 1997, 491 (comment on fig. 34) prefers an over-life-size bronze statue in Basel, which is generally considered Hel. lenistic. Krumeich 1997, 69-71, 244 cat. A 59 lists all possible attributions but accepts none; his catalogue entry refers to the literary source. 
It seems methodologically unsound to defend the merit of each attribution and identification by using both the ancient sources and the extant replicas together, to support one another; the resulting arguments risk being circular. The literary sources, at best, are not very explicit; at worst, they can be confused or slanted, according to the date and the intention of the writer. The alleged replicas, usually carved long after the assumed prototypes, may have been considerably modified, even invented outright, to suit the taste and demands of Roman customers. Indeed, some heads recognizably reproducing the same portrait type exhibit elements typical of their own period, such as lunate pupils, extensive drill work in hair and beard, stylized features, and so on. ${ }^{5}$ To be sure, individual physiognomic traits are not to be expected in fifth-century portraits, and in our case a general fifth-century appearance should suffice to validate the attribution. Yet styles, especially Clas. sical, could be imitated at any later time, and there. fore stylistic features alone are insufficient to determine which famous individual is being depicted. Finally, circular arguments can easily be constructed on the basis of perceived similarities that inevitably carry a certain amount of subjectivity. I shall here try to separate the various categories of evidence, especially with reference to Anakreon.

\section{THE LITERARY SOURCES}

Little is known for sure about the poet from Teos. Historians and philologists who have attempted to reconstruct his life on the basis of his poems and other ancient sources have produced different outlines. Everybody agrees that Anakreon was born ca. 575-570 and that he left his native city, after the Persian Harpagos's attack around 540, with the people who founded Abdera on Thrace. After this point, opinions diverge. Some commentators would make Anakreon go from Abdera to Samos, perhaps sum. moned by Polykrates' father. He was still there at Polykrates' death in 522, which is probably when Hipparchos had him fetched to Athens by a 50 -oared

\footnotetext{
${ }^{5}$ For these strictures applied to replicas of the Anakreon, see, e.g., $P O G$ 1965, 75-78, nos. 2, 3, 6. The entire range of possible alterations is well exemplified by Sokrates' portraits (supra n. 2).

${ }^{6}$ Campbell 1988, 154-55, no. 107D (Anth. Pal. 6.142) and 156-57, no. 108D (Anth. Pal. 6.136). Cf. also Bowra 1961, $300-301$.

${ }^{7}$ The most influential proponent of the first version (Abdera-Samos-Athens-Pharsalos-Teos) is Bowra 1961, 284-316. He is followed, e.g., by Richter (POG 1965), and, most recently, by $O C D^{3}$ (1996) 79-80, s.v. Anacreon (C. Carey); less explicit about the length of the Athenian stay, and more doubtful about the Thessalian visit: Der Neue
}

military ship. The poet seems to have lived a merry life at the court of the Peisistratids until Hipparchos's murder in 514, or even until Hippias's expulsion in 510. Anakreon might then have fled to Thessaly, on the evidence of two epigrams attributed to him and addressed to the king of Pharsalos and his queen. ${ }^{6}$ From there he perhaps returned to Teos, since two epitaphs, once attributed to Simonides but certainly later, mention the site as his burial place. He seems to have died (aged 85 - an old man) ca. 485. A different reconstruction sees Anakreon going to Athens even before his stay at the court of Polykrates, and would then make the poet either remain in Athens after 510 , or return there from Thessaly in the early fifth century, to live there for much of his later life. These variant versions would be of little import, were it not that Anakreon's Athenian interludes may be relevant to the interpretation of Pausanias's passage about the Akropolis statues. ${ }^{7}$

There is no doubt that Anakreon enjoyed a friendly relationship with Polykrates (ruled 533-522), not only on the testimony of his own verses, ${ }^{8}$ but also because Herodotos (3.122) mentions that the two were at table together when Oroetes' messenger called - the beginning of the events that led to the Samian tyrant's death. There is also no question that the poet went to Athens after that time. But was he in Athens even prior to his Samian stage? The assumption is based on a passage of Himerios $(\mathrm{Or}$. 39.10), who states that Anakreon "was glad to address the great Xanthippos" when he was sent to, or sum-

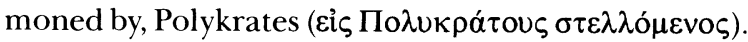
This is the only ancient source that connects the poet and the Athenian, but it has been used in conjunction with Pausanias's mention of the Akropolis statues to postulate a friendship between the two. $\mathrm{Hi}$ merios is a late source (fourth century A.D.), and it is usually admitted that the passage may be "muddled." Nonetheless, possible emendations eliminating Xanthippos's name have been rejected, and one scholar has argued that the context of Himerios's statement (citing precedents for his own address to

Pauly 1 (1996) cols. 646-49, s.v. Anakreon (E. Robbins, trans A. Wittenburg). The second version (Abdera-AthensSamos-Athens-[Pharsalos?]-Athens-[Teos?]) is advocated by Campbell 1988, who includes and discusses all the testimonia, the actual fragments by Anakreon, and the Anakreontea, written in imitation of the Tean's poetry, from ca the first century B.C. to the sixth or seventh century A.D. A similar position is held by Rosenmeyer 1992, 14. Zanker 1995 seems to believe that Anakreon died at Athens.

${ }^{8}$ According to Strabo 14.1.16, Anakreon's poetry was full of references to Polykrates: see Campbell 1988, 130-31, no. 483, and cf. Ael. VH 9.4 (Campbell 1988, 92-93, no. 414) 
the emperor Julian) supports its cogency, at least for its author. ${ }^{9}$ Trying to accept it literally forces the Athens-Samos-Athens sequence of Anakreon's travels, and a possible explanation suggests that the poet honored the Athenian as a kalos in a pederastic context. The Peisistratids may have sent an embassy to Polykrates, for which the poem containing the in vocation to Xanthippos was produced. ${ }^{10}$

Himerios's passage could be discounted in terms of the sequence of voyages and locales, yet still be useful as evidence of Anakreon's admiration for Xanthippos during the poet's stay in Athens after 522. The assumption is generally made that the two met at the court of the Peisistratids, at those symposia which the poet so highly praised and enjoyed. Yet chronology may be somewhat forced nonetheless. Xanthippos was probably born by $520,{ }^{11}$ was married (to the Alkmeonid Agariste) no later than 496 (since Perikles, his second child, was born ca. 494), and ostracized in 484/3. He returned to Athens at the time of the Persian threat, was elected one of the strategoi in 479, and sent to Sparta as member of an embassy. He was mainly known (even to Pausanias: 1.25.1) for having served in the fleet that, in that same year, destroyed the Persian navy at Mykale. In 479/8, he recovered Sestos (in the Chersonnesos), his last recorded deed. He was presumably dead in the mid-470s, perhaps killed in military action, and was certainly out of the picture by $473 / 2$, when his

\footnotetext{
${ }^{9}$ Bowra 1961. He adds, however, that it is "most unlikely" that Anakreon met Xanthippos at the court of Polykrates, and suggests that Himerios might have mistakenly connected with Samos some poem of Anakreon in which Xanthippos was mentioned.

10 This solution is proposed by T.J. Figueira, "Xanthippos, Father of Perikles, and the Prutaneis of the Naukraroi," Historia 35 (1986) 257-79, esp. 277 and n. 76, with additional references. Note, however, that Figueira supports his sug. gestion with the traditional "evidence" of the Akropolis statues and their association; the point is, at any rate, irrelevant to his main, historical, argument. Strictly speaking, Anakreon could have addressed Xanthippos in his verses, on commission, even if the Athenian were relatively unknown to him, in the same manner in which an epinikion could be written for a relatively unknown victor. The mention should therefore not be read as evidence of friendship between Xanthippos and Anakreon.

${ }^{11}$ J.K. Davies, Athenian Propertied Families (Oxford 1971) $455-60$, no. 11811 is my main source of information. On p. 456 he places Xanthippos's birth date ca. 520, but adds that the Athenian could have been born from 10 to 15 years earlier, "if there is anything in the confused tradition connecting Xanthippos and Anakreon." On Xanthippos (I), see also $O C D^{3}$ (1996) 1627, s.v. Xanthippos 1 (P. Treves, P.J. Rhodes), who agree with Davies. Krumeich 1997, 69 accepts the wider span: between 535 and 520. For the possible rea-
}

son Perikles acted as choregos for Aischylos and was said to be "his own master." According to this chronological schema, Anakreon would have arrived in Athens even before Xanthippos's birth, or at least when the latter was very young, and have left (in 514 or 510) before the bonds of a true friendship could be established.

To support the theory of a close association between the two men, some scholars postulate, as already mentioned, that Anakreon returned to Athens shortly after fleeing to Thessaly, ${ }^{12}$ or even that he never left after Hippias's expulsion. Yet the sympotic lifestyle suggested by Anakreon's own verses would have diminished considerably with the down. fall of the tyrants, and so too the occasions for close encounters with a young Xanthippos. A friendship between men is still possible, but Xanthippos's marriage, military activity, and ostracism would have provided few opportunities. By 485, moreover, Anakreon was dead.

This allegedly lengthy stay of Anakreon in Athens finds apparent support in two additional Athenian connections: the poet is said to have enjoyed Aischylos's songs and to have loved Kritias (Schol. Aisch. P.V. 128). On this second score, no less an authority than Plato, in his Charmides (157e), has Sokrates remind the younger Kritias (the son of Kallaischros, later one of the Thirty Tyrants) that both Solon and Anakreon had sung the praises of his father's house,

sons for his ostracism, cf. Figueira (supra n. 10), who thinks Xanthippos was held responsible for the relative lack of preparation (and hence the delay) of the Athenian navy at the time of the attempted coup on Aigina.

12 See, e.g., Rosenmeyer 1992, 14; but the evidence she gives in her n. 10 is limited to Pausanias and Himerios, and (p. 28) she admits that we cannot be sure of the links between the individual statues on the Akropolis, or that Perikles commissioned them.

Himerios calls him "the great Xanthippos," but this appellation is unlikely to have been deserved before the Athenian's actions at Mykale and Sestos and therefore should not be considered a true echo of Anakreon's verses, since the poet was dead by the time of those victories. An. other possible scenario is that Anakreon's poem referred to a different Xanthippos, who was implicitly equated by Himerios with the more famous one known to him. The name Xanthippos is relatively common, and Davies (supra n. 11) 456 mentions that another person by that name, perhaps a cousin of Perikles' father, was archon in Athens in 479/8 (PA 11159) - cf. P.M. Fraser and E. Matthews eds., $A$ Lexicon of Greek Personal Names 2, Attica (edited by M.J. Os. borne and S.G. Byrne; Oxford 1994) 344, s.v. Xanthippos, no. 2. Another Xanthippos (1) is listed as belonging to the fifth century, and a total of 25 individuals by that name are known from Athens through the Hellenistic period. 


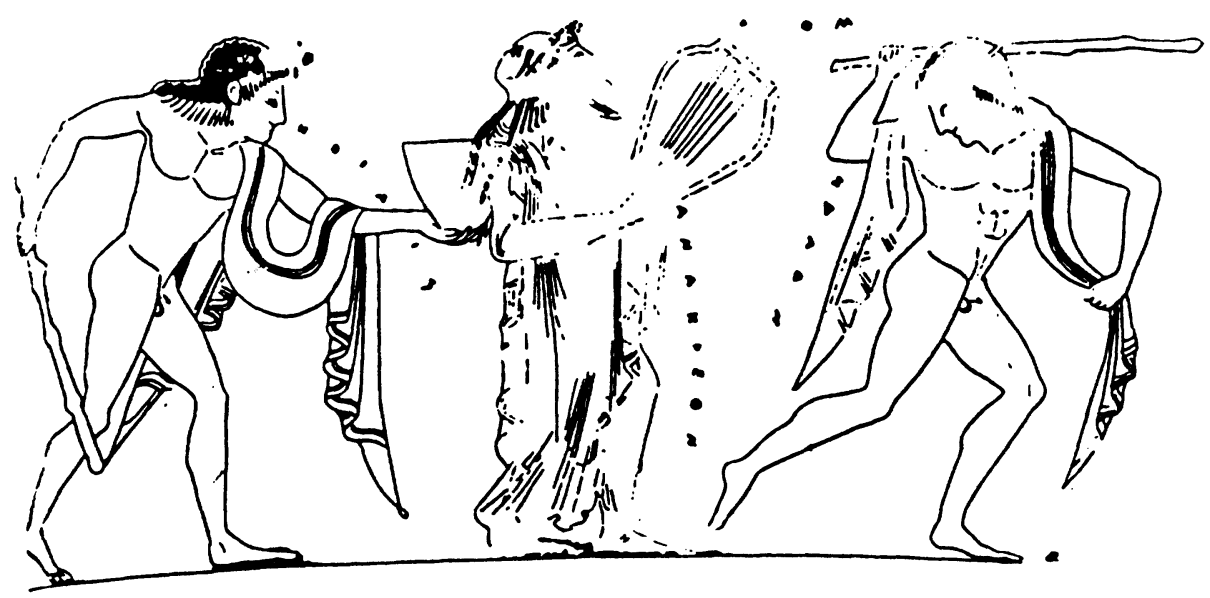

Fig. 1. Attic red-figure lekythos by the Gales Painter, Syracuse Museum, inv. 26967. (After Price 1990, pl. 3b)

the home of Kritias son of Dropides. ${ }^{13}$ With Aischy. los, the chronological reference is ambiguous. The dramatist's first play was staged in 499 , and his first victory was won in 484 , but he was old enough to fight at Marathon, and may have composed songs before embarking directly on writing tragedies. Anakreon may have enjoyed his verses before 510, or, if later, not necessarily while residing in Athens. As for Kritias, the evidence is stronger but need not extend past 510. The grandfather of the politician was probably born ca. 530, so that he could have been loved, or at least admired, by Anakreon before Hipparchos's murder. ${ }^{14}$

At any rate, the younger Kritias (as cited by Athe naios) has left us a telling picture of how Anakreon was remembered by his generation, probably in the 440s-430s: "Teos brought to Hellas sweet Anakreon, the weaver once of songs for women's melodies, the awaker of revels, the deceiver of women, rival of flutes, lover of the lyre, sweet anodyne against sorrow. Never shall love of thee grow old or die, so long as the boy bears round water mingled in cups with

${ }^{13}$ For these citations, see Campbell 1988, fr. 495, pp. 136-37 (Plato); fr. 412, pp. 90-91 (Schol. Aischyl.; the Greek term used is $\mu \varepsilon \dot{\varepsilon} \lambda \varepsilon \sigma \mathrm{l}$, that is, from $\mu \dot{\varepsilon} \lambda \eta$, lyric poetry); cf. also test[imonium] 8 (Lucian Macr. 26), pp. 28-29 and n. 1, on length of Anakreon's life based on Aischylos's plays.

${ }_{14}$ Once again, I draw my information primarily from Davies (supra n. 11) no. 8792, esp. pp. 324-27. Kritias (III) was the father of Kallaischros ca. 500, and a candidate for ostracism in the $480 \mathrm{~s}$. Kritias (IV), who later became one of the Thirty Tyrants, was probably born ca. 460; on him, see also $O C D^{3}$ (1996) 409-10, s.v. Critias (M. Gagarin) and cf. 26-29, s.v. Aeschylus (A.H. Sommerstein), for an account on the playwright. His life span is given as ca. 525-456/5.

${ }^{15}$ I have cited the translation in Bowra 1961, 307-308, but cf. also Campbell 1988, fr. 500, pp. 138-39 (Ath. $13.600 \mathrm{~d}-\mathrm{e}$, Scholars at Dinner). Songs for women's rituals wine and distributes the drinks around, so long as the maiden companies keep their holy all-night festivals, and the scale, daughter of bronze, sits on the top of the tall kottabos-pole for the throwing of the wine-god's drops."15

This characterization of Anakreon as a reveler and sweet singer has been strengthened by some visual evidence that has also been adduced to support a return of the poet to Athens after a Thessalian interlude. Some red-figure vases showing a lyre-player in long chiton are inscribed "Anakreon," thus identifying the image with the Tean bard (fig. 1). An apparent gap of approximately 20 years (from ca. 520 to ca. 500-490) between labeled representations, it was pointed out, cannot prove Anakreon's absence from Athens, but neither can it disprove it. Yet a more recent study has placed the inscribed vessels in a line of similar depictions (figs. 2-4) that extend in time in both directions, without notable interruptions, and has suggested that these "Anakreontic vases," as they are usually called, echo burlesque and theatrical dances-performances that in Athens,

have not been preserved within the corpus of Anakreon's works, but Kritias, as a source relatively close in time to the Tean poet, should have been well informed. S. Brusini, "L'Anacreonte Borghese: Una nuova proposta di lettura," RdA 20 (1996) 59-74 uses the poem to suggest that Anakreon's statue was meant to express the ethical, edu. cational value of music, specifically that of the barbiton against that of the aulos, in light of the debate current in fifth-century Athens, and pushes further the theory advanced by Zanker 1995 about the well-behaved symposiast. Although she accepts the traditional interpretation, she makes valuable suggestions about the Copenhagen statue, which she would restore with a barbiton on the left hip and perhaps a cup in the right hand, thus explaining Pausanias's comment. 


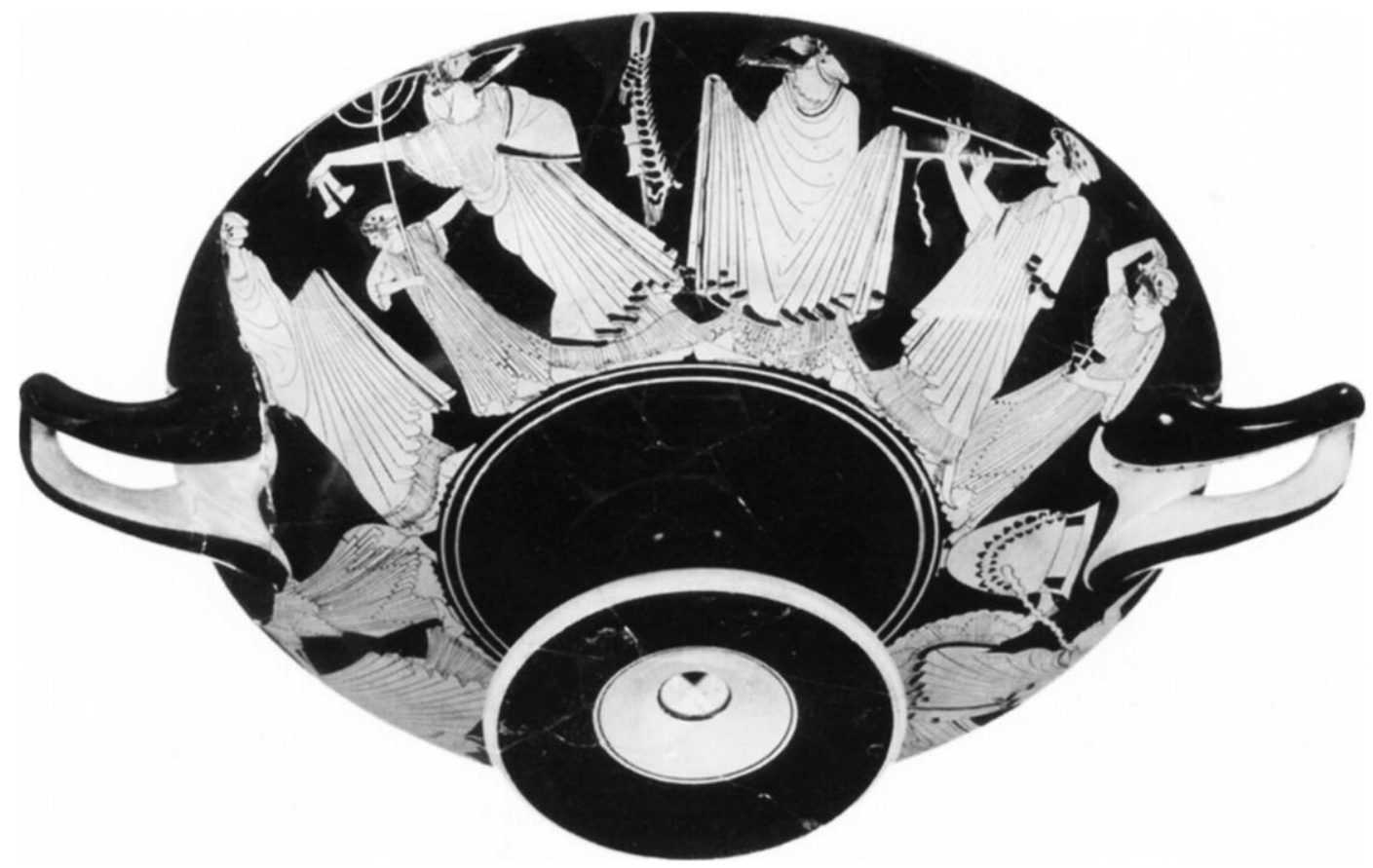

Fig. 2. Attic red-figure cup by the Briseis Painter and the potter Brygos, side A. Malibu, J. Paul Getty Museum, 86.AE.293. (Photo courtesy Museum)

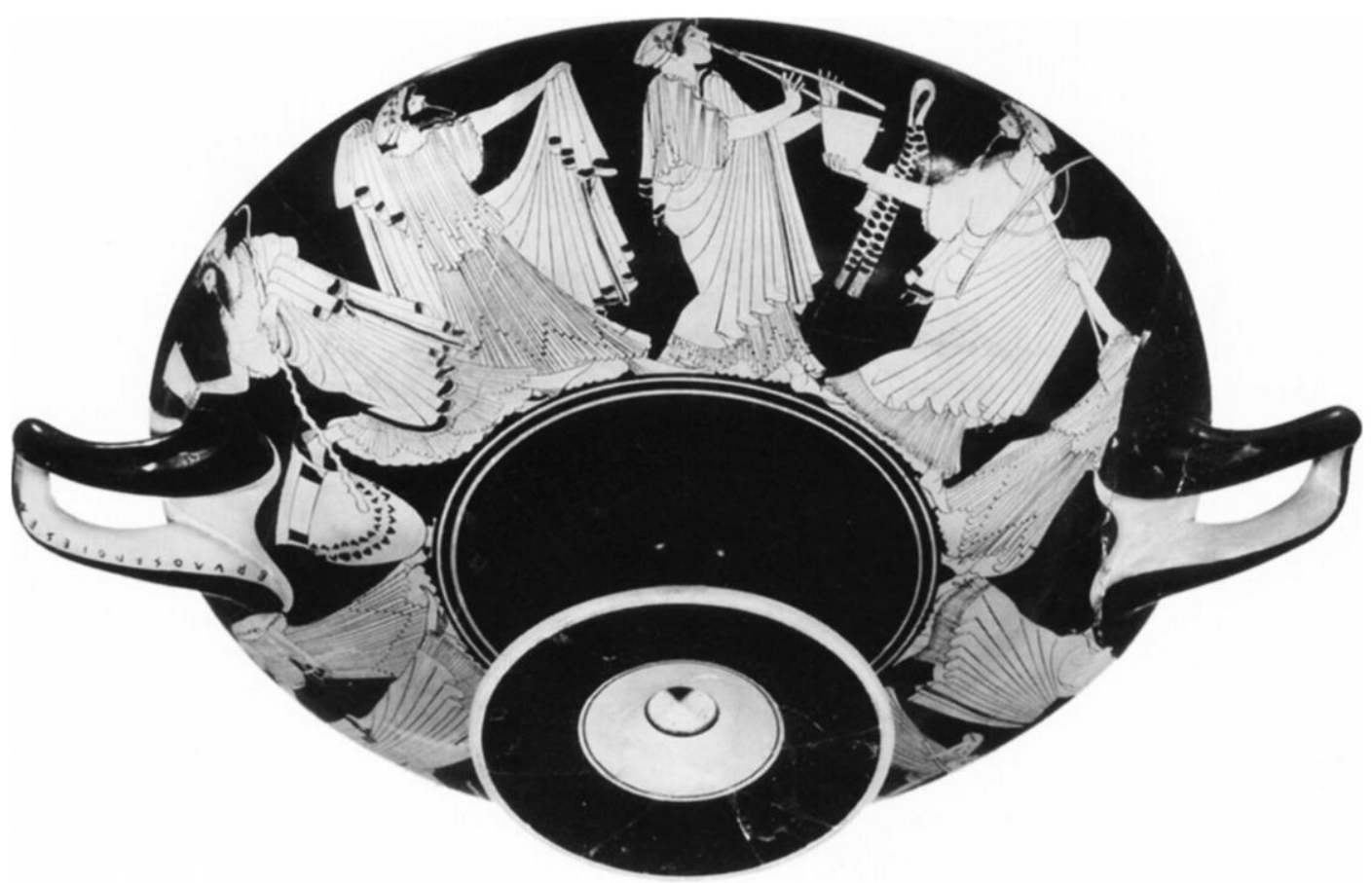

Fig. 3. Attic red-figure cup 86.AE.293, side B. (Photo courtesy J. Paul Getty Museum) 


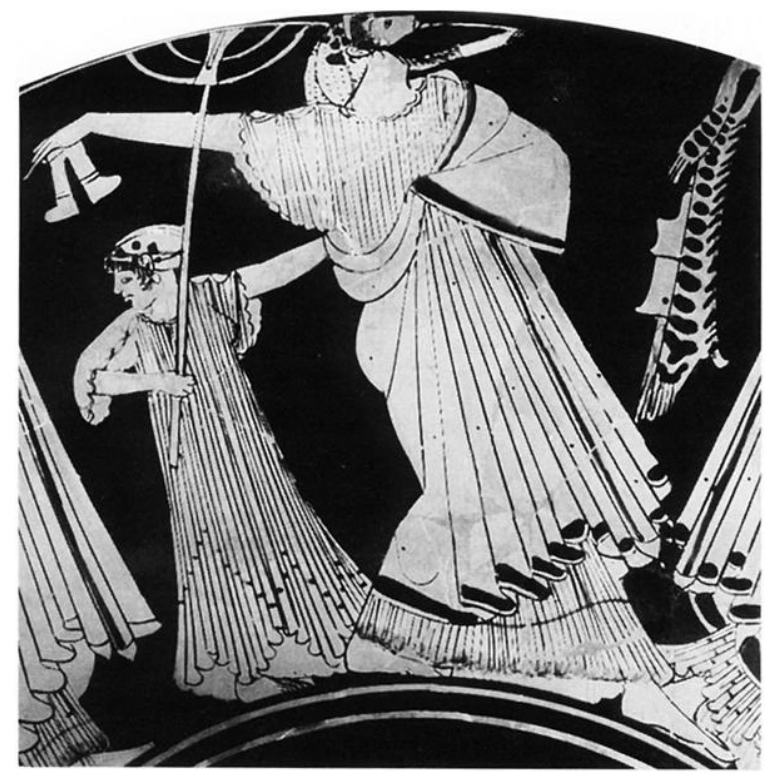

Fig. 4. Attic red-figure cup 86.AE.293, detail of side A. (Photo courtesy J. Paul Getty Museum)

after the fall of the Peisistratids, assumed a parody character in keeping with the reaction against the luxurious lifestyle promoted by the tyrants. ${ }^{16}$

In summary, it would seem that Anakreon's presence in Athens, after his stay with Polykrates and until the Peisistratids' demise, can be established through reliable Classical sources (Herodotos, Plato, Aristophanes), ${ }^{17}$ as well as his own poems. An earlier and a later Athenian stage, however, cannot be

${ }^{16}$ The gap as possible index of Anakreon's Thessalian sojourn: S. Papaspyridi Karouzou, "Anacréon à Athènes," BCH 66-67 (1942-1943) 248-54. She states that perhaps the Athenians brought Anakreon back because they did not hold against a poet his association with the tyrants; he was, however, old and balding, by that time, and was thus portrayed on the vases. Karouzou's article is cited with approval by Campbell 1988, 26-27, test. 6 n. 1. A similar position is held by Rosenmeyer 1992, 29-33, who sees confirmation of a Thessalian stay in the fact that Simonides of Keos, who was at the Peisistratids' court at the same time, went to live in Thessaly ca. 510. See, however, Price 1990, 137 for a statement against Anakreon's return to Athens on the basis of a "circular assumption" that the vases represent actual individuals. Price includes Chiot chalices (first half of the sixth century) in her consideration of "Anakreontic" scenes and convincingly argues that the images depict revelers and Ionic poets in general, the Attic black. figure series beginning ca. 560 down to 520 and continuing in red figure from ca. 510 to 450 , long after the end of Anakreon's plausible life span. A somewhat similar point of view is held by Boardman in D. Kurtz and J. Boardman, "Booners," Greek Vases in the J. Paul Getty Museum 3 (1986) 35-70. Although he too believes in Anakreon's return to Athens from Thessaly (p. 67), he sees the Anakreontic vases demonstrated: neither the late Himerios nor the Aischylean scholiast provides adequate evidence, and not even the Attic red-figure vases, once they are seen in their proper context. If therefore an alleged friendship between Xanthippos and Anakreon can be discounted on chronological grounds, it now remains to see at what time a statue of the poet could plausibly have been erected.

Because of Pausanias's wording, as already mentioned, the association of Anakreon's image with that of Xanthippos has been taken for granted. Yet the periegete tends to list monuments one after the other, as he sees them, without truly meaningful patterns. He uses the same adverb (plesion) to describe the statues of two mythical heroines, Ino and Kallisto, near the Anakreon; yet no specific link with the poet is intended. Occasionally, the association may be only in Pausanias's mind, as when he cites together the bronze boy with the sprinkler by Myron's son Lykios and the Perseus killing Medusa by Myron himself (1.23.8). At times, his descriptions seem to leap over areas; at others, to proceed systematically from monument to monument. Perhaps we have read too much into Pausanias's account. In addition, statues on the Akropolis were often removed, if damaged, or, when in bronze, even melted down to serve other purposes. The Anakreon and the Xanthippos may have owed their mid-second-century A.D. proximity to one such "landscaping" action, which may not have reflected original settings. ${ }^{18}$

Even assuming that the two images were left un-

as indication of strong Ionicizing tendencies that cannot be attributed to "a single Ionic immigrant" (p. 47). For him, however, the painted scenes contain no hint of parody or effeminate characterization. Rosenmeyer's interpretation of the vases seems to me too literal, although she makes the important point (p. 33) that they place the poet in a sympotic context well before the Hellenistic characteriza. tion of Anakreon as typically drunk. M.H. Delavaud-Roux, "Lénigme des danseurs barbus au parasol et les vases 'des Lénéennes'," RA 1995, 227-63 adds one more group of red-figure vases to Boardman's and Price's lists (cf. her pp. 254-58 for a special critique) and suggests parody of maenadic dances, placing special emphasis on the parasol as an element of female costume.

${ }^{17}$ Ar. Thesm. 159-63. On these verses, see also infra.

18 See, $\mathrm{t} \rightarrow$ D. Harris, "Bronze Statues on the Athenian Acropolis: The Evidence of a Lycurgan Inventory," AJA 96 (1992) 637-52, and, more extensively, Harris, The Treasures of the Parthenon and Erechtheion (Oxford 1995) for the kind of rearrangements that could take place on the citadel. Pausanias is thought to have written his book 1, on Attica, between ca. A.D. 155 and 160/61: C. Habicht, Pausanias' Guide to Ancient Greece (Berkeley 1985) 11. For Pausanias's way of describing monuments, see, e.g., H.A. Thompson and R.E. Wycherley, Agora XIV: The Agora of Athens. The History, Shape 
touched until the time when Pausanias saw them, we should consider whether Perikles, who is generally said - although on no objective grounds - to have dedicated both, would have wanted to stress his father's association with a "tyrannical" poet. Xanthippos's father, Ariphron, was probably a partisan of Peisistratos ( $P$ Oxy. 4.664), yet neither he nor his son were accused by the Athenians of pro-tyrant favoritism. Xanthippos's ostracism was not caused by his friendship with the Peisistratids, and the Athenaion politeia (22.6) seems to distinguish him from other such friends. ${ }^{19}$ If, indeed, Anakreon, in the Athenians' minds, stood for the luxury living of the tyrants, would Perikles have intentionally hinted at his father's relationship with that circle? Those who believe that the Copenhagen statue copies the Akropolis portrait argue that the type of representation (whether its almost total nudity is seen as "heroic" or otherwise) effectively divorces it from such mental associations, ${ }^{20}$ but this argument is circular, being based on another assumption - no certainty in fact exists that the Ny Carlsberg Anakreon replicates the Athenian monument. We shall discuss it separately below.

Perikles himself, despite his Alkmeonid pedigree, seems to have projected himself as a champion of

and Uses of an Ancient City Center (Princeton 1972) 204-207. Although excavation has confirmed the periegete's accuracy in many instances, in some areas he seems to proceed "in a series of jumps" (p. 205) and "he is often distressingly vague ... in matters of distance and direction and the relation of adjacent monuments to one another" (p. 204). See also Wycherley, Agora III: Literary and Epigraphical Testimonia (Princeton 1957) 11: for Pausanias, "nearby" can mean a few feet or $50 \mathrm{~m}$.

I find now that Krumeich 1997, 70 n. 162 makes the same point about the statues of Io and Kallisto, adding that the two are clearly mentioned by Pausanias as a group, whereas no such indication is given about the Anakreon and the Xanthippos, who therefore formed surely no group in a strict sense. In $\mathrm{n} .164$ he points out that Pausanias gives no hint as to a possible friendship between Xanthippos and Anakreon.

${ }^{19}$ See Figueira (supra n. 10), e.g., 278: "Remarkably, Ariphron and Xanthippos were not tainted by their associations with Peisistratos."

${ }^{20}$ Zanker 1995, 22-31 asks exactly the same questions, but he gives a different answer, which shall be discussed infra. Although he admits that the friendship between Anakreon and Xanthippos is based on uncertain evidence (p. 22), he still believes that the two images were somehow connected (even chronologically) because of Pausanias's wording (p. 24). Schefold 1997, 102 goes so far as to state that the connection with Anakreon was one of the glories of Perikles' family.

${ }^{21}$ For a balanced account of Perikles' policies, see, e.g., J. Ober, Mass and Elite in Democratic Athens: Rhetoric, Ideology, the people, favoring the masses over the elite. It is understandable that he might have wanted to remind the Athenians of his father's victories at Mykale and Sestos, but presumably not of his leanings toward the aristocratic modes for which the Tean poet was still remembered, at least by Aristophanes and Kritias the politician. ${ }^{21}$ To be sure, Anakreon's fame as a poet may have placed him above all factions, but his period of greatest popularity seems to have come a bit later. In the fourth century, compilations of his works were made, and a major revival took place by the end of the second or the beginning of the first century, when imitations of Anakreon's meters and poetry were produced that could later pass as the poet's own. They certainly were appreciated by Aulus Gellius in the mid-second century A.D. These imitations continued to be made until at least the sixth or seventh century A.D. and form the corpus now called the Anakreontea. ${ }^{22}$ Thus, theoretically, a monument to Anakreon could have been set up at any time, from his death until well down into the Roman period. Literary descriptions of statues (at Athens, Teos, Kyzikos, and perhaps elsewhere) portraying the poet drunk have been said to reflect a conception that arose in the Hellenistic period, probably at Alexandria. ${ }^{23}$ The Akropolis

and the Power of the People (Princeton 1989) 86-91. Krumeich 1997, 71 assumes that Xanthippos's statue was placed on the Akropolis (probably by himself or his relatives) after the military events at Mykale and the Hellespont, therefore shortly after 478; since Xanthippos was relatively little known, a fourth-century portrait of him is considered unlikely. Krumeich accepts the Copenhagen Anakreon as a replica of the Akropolis image, but believes that the latter was set up around 450-440, by an unknown dedicator; he finds it inadequate as an oligarchic response to the democratic building program by Perikles, as proposed by Voutiras (see infra n. 36).

${ }^{22}$ See Campbell 1988, 4 (and cf. fr. 372, pp. 64-65) on Chamaileon and Herakleides Pontikos, who wrote treatises and compilations of Anakreon's poems; others were made by the Alexandrians. For the chronological range of the Anakreontea, see his pp. 10-18. Aul. Gell. NA 19.9 quotes one of these imitations as "the charming little verses of aged Anakreon." His book was probably published shortly before A.D. 180 (p. 12). See also $O C D^{3}$ (1996) 80, s.v. Anacreontea (M.L. West) ("some 62 Greek poems" being composed as late as the fifth or sixth century A.D.).

${ }^{23}$ Poulsen 1931, 4. Particularly telling is the epigram by Leonidas of Tarentum (Anth. Lyr. Graec. 16.306): cf. Campbell 1988, 30-33 test. 11. A more nuanced discussion of Anakreon's conception through the ages is in Rosenmeyer 1992 (cf. also supra n. 16). She would accept that "Alexandrian 'realism' ... turned Anacreon into the complete drunkard" (p. 19), but also believes that fifth-century Athens knew two different statuary types of the poet: the inebriated one described by Pausanias and the sober, mas- 
portrait (because of Pausanias's mention, definitely dating before ca. A.D. 150) could even have been placed next to a preexisting image of Xanthippos by those who realized that the two men were approximately contemporary, whether or not a special friendship was understood to have existed. ${ }^{24}$

Reviewing in brief what is factually known about the dedication of the three Akropolis monuments-the Perikles, the Xanthippos, and the Anakreon - we find that not a single date for them is sure. No base has been associated with the last two. A fragmentary inscription on a broken pedes

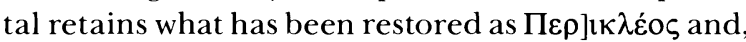

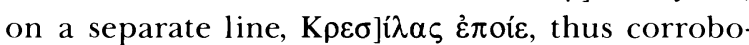
rating Pliny's information. The reading of the two names, however, is by no means assured, and other possibilities have been suggested. Even those schol. ars who accept the mention of Perikles on the stone have to explain why the genitive form is used. Some assume that it gives the patronymic of the dedicant, and see the offering as made by Xanthippos, son of Perikles; the identity of the statue would, however,

culine Anakreon reflected by the Copenhagen statue (pp. 28-29). Her belief seems to arise from her acceptance of a fifth-century date for the Akropolis monument, although Pausanias does not specify its chronology.

The statues in Teos are mentioned in POG 1965; the one in Kyzikos is cited by Campbell 1988, 31, test. 10, n. 2 (W. Peek, Griechische Vers-Inschriften 1 [Berlin 1955] 1792.1-3).

${ }^{24}$ A typical example of this practice is the statue of Timotheos (died 355 or 352), which was set up on the same curved base as the earlier one of his father Konon (died ca. 390), both statues presumably posthumous. Pausanias (1.24.3) mentions the two images together, without making a chronological distinction; but see the evidence of the $b_{c} \rightarrow$ G.P. Stevens, "The Northeast Corner of the Parthenon," Hesperia 15 (1946) 1-26, esp. 4-10, figs. 5-11 (fig. 9 gives a tentative reconstruction of the two phases, based in part on the centering of the inscription). This example is cited by A.H. Borbein, "Polykleitos," in O. Palagia and J.J. Pollitt eds., Personal Styles in Greek Sculpture (YCS 30, Cambridge 1996) 66-90, with the comment that "it happened fairly often in Greece that figures were added to monuments already in existence" (p. 82 and n. 97). See also C.M. Keesling, "Property and Piety: Joint Dedications on the Late Archaic and Early Classical Athenian Acropolis," AJA 98 (1994) 322 (abstract). She has calculated that of 33 examples, only eight dedications were set up by persons with a clear family relationship; 24 , however, are uncertain and some can be proven to have been erected by clearly unrelated dedicants, some contributing to existing offerings. She stresses the chronological implications of a son adding to his father's gift, or other similar cases. I do not believe, however, that the Xanthippos and the Anakreon could have shared a single base, given their differing subjectsadditions to previous offerings usually consisted of objects suitable as gifts to the divinity, not as commemoration of specific individuals. remain unstated by the inscription. Others compare the form to funerary formulas, where words such as sema or mnema would be implied and automatically supplied by the reader. In the first instance, the dedication by Perikles' son would have had to be made before 429, since the statesman's legitimate children both died during the plague that killed the father as well. Yet there is a dearth of commemora. tive statues of political figures on the Akropolis for almost the entire fifth century (this consideration could apply also to Xanthippos's image). If the second solution is adopted, Perikles would have been already dead, and therefore no inference can be drawn from this base about the maker and the chronology of the Xanthippos and the Anakreon. All deductions, at this point, are usually made on the basis of the available portraits as known through the Roman copies, therefore on perilous stylistic grounds, and on the assumption that their prototypes stood on the Athenian citadel. ${ }^{25}$ I shall here express my tentative opinion.

Perikles was held in great respect even after his

For a meaningful juxtaposition of statues created at different times, see also the theory by I. Worthington, "The Siting of Demosthenes' Statue,” BSA 81 (1986) 389. We do not have sufficient evidence to suggest that the Romans (or the Greeks of the Roman period) promoted some of these sculptural combinations.

${ }^{25}$ Fragmentary Akropolis base: $I G \mathrm{I}^{2}, 528$. A.E. Raubitschek, Dedications from the Athenian Akropolis (Cambridge, Mass. 1949) 139-41 and 510-13, no. 131, originally had considered only the first piece, but, under L. Jeffery's influ. ence, added to it a second inscribed fragment, $I G \mathrm{I}^{2}, 635$, which provided the names of several individuals, thus elim. inating any connection with Perikles, although Kresilas's signature was retained. In a later article, however, "Zur Per. iklesstatue des Kresilas," ArchCl 25-26 (1973-1974) 620-21, Raubitschek, returning to his original opinion, proposed that the two fragments be separated, and that the first be

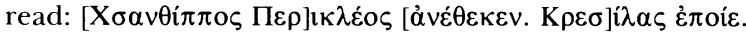
He therefore saw the inscription as belonging to a statue of Perikles set up by his son. Richter (POG 1965), who had already accepted the separation of the two fragments, stressed the funerary formulation, however, and suggested that Perikles' portrait was dedicated by the Athenians after the statesman's death. J. Marcadé, Recueil des signatures de sculpteurs grecs 1 (Paris 1953) 63 recto, s.v. Kresilas, published the two fragments together and stated that the individuals thus listed could not be specifically identified. He, how. ever, completed the epoie to read epoiesen, in keeping with other signatures of Kresilas. Should the form epoie be re. tained, as apparently accepted in Raubitschek's article, the use of the imperfect tense instead of the aorist may in. dicate a date later than Kresilas's activity and would cer. tainly differ from the master's practice.

Hölscher 1975, 194 and ns. 62-63 prefers Richter's reading and believes that the portrait seen by Pausanias could hardly have been dedicated by Perikles himself. He points 
death, as suggested not only by Thucydides' account of him, but also by Pliny's notice $(H N$ 35.137) that Aristolaos, a fourth-century painter, depicted the statesman. The statue seen by Pausanias might have been set up after 429 . The same could apply to the Anakreon, especially since poets' portraits presumably did not become popular until the fourth century. One more argument for a fifth-century date, on the grounds that a sculptor around 440 might have remembered Anakreon's approximate appearance, is made implausible not only by the standard Classical approach to likenesses, but also by the impossibility of such remembrance, if the Tean poet had left Athens after 514 or $510 .{ }^{26}$ Xanthippos's portrait would seem to demand an earlier date, but it could have been erected (by Perikles?) in the immediate aftermath of the Persian Wars, when such commemorative monuments as the Marathon group

out (pp. 192-93) that no statues of living politicians, whether on the Akropolis or elsewhere, had been erected since the Persian Wars. Hafner (supra n. 4) 1-2 and ns. 2 and 7 believes that the two base fragments are unrelated (because of the lack of word separators on the "Kresilas" piece), but

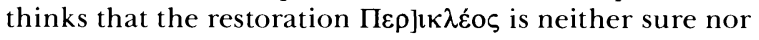
even plausible, since Perikles' patronymic would be lacking. His dating of all three portraits (Xanthippos, Anakreon, and Perikles) to a time before 438 is based primar. ily, as already mentioned, on his inferences about their imitation on the shield of the Athena Parthenos - an anecdote discounted by F. Preißhofen, "Phidias-Daedalus auf dem Schild der Athena Parthenos?” JdI 89 (1974) 50-69. The issue of the Akropolis base is now discussed also by Krumeich 1997, 116-17, who would accept Kresilas's sig. nature but is uncertain whether Perikles' son was the dedicator, since at least 73 personal names end in ikles. The subject of the dedication, moreover, could be Perikles' son's own portrait as well as a mythological figure.

${ }^{26}$ The statement about a remembered appearance of the poet is made by Richter, $P O G$ 1965, 77, although she speaks only of approximation; her chronology is, of course, largely based on the assumption that the Copenhagen statue, which she dates on style, copies the one on the Akropolis. On the other hand, she admits (p. 6) that invented portraits were created throughout the history of Greek portraiture - a statement repeated in the abridged edition of $P O G$ (Smith [supra n. 4] 18). For poets' statues in general, see $P O G$ 1965, 5; cf. Schefold 1997, 44. Even this latest publication, for the entire period from ca. 480 to ca. 380 , can show only four "portraits" of poets: Homer, Anakreon, Pindar (formerly Pausanias), and the so-called "Walking Poet" in the Louvre (Ma 588), who is tentatively identified as Archilochos - all of them dated solely on stylistic grounds and from Roman copies. Other sculptures include three original reliefs (the so-called-but uninscribed-stele of Diotima, a priestess; the gravestone of an actor, perhaps Aristophanes, in Lyme Park; and a grave stele of a man with a lyre, not further identified, in Basel). The collection of portraits is therefore filled in by the Perikles, the Themistokles, the so-called Pastoret Head identified as Kononnone of them a poet - and the bronze Porticello head, con sidered Anacharsis, on very tenuous grounds. All other at Delphi and the painting of the same battle by $\mathrm{Mi}$ kon and Panainos in the Stoa Poikile included the "portrait" of Miltiades (Paus. 1.15.4). ${ }^{27}$ Note, however, if any special significance can be attributed to Pausanias's choice of words, that the Perikles and the Athena Lemnia are described as dedications (anathemata), whereas the Xanthippos and the Anakreon are called by their respective names.

\section{THE SCULPTURAL EVIDENCE}

It is unnecessary, in this context, to go over the issue of Perikles' portraits, which I have discussed elsewhere. I retain my opinion that "evidence is inadequate either to assert or to deny that the extant herms copy the Akropolis statue," especially, as I maintain, if religious restrictions of some kind existed about the exact copying of freestanding monuments in major sanctuaries. ${ }^{28}$ The surviving por-

images cited occur on vases, coins, and even an engraved mirror, which cannot count at the same level as public monuments and sculptured portraits, whether imaginary or real.

${ }^{27}$ For Miltiades' portraits, see Paus. 10.10.1-2 (Delphi) and 1.15.4 (Athens). The issue of the portrait of Themistokles is still debated, the prototype for the inscribed Ostia herm having been variously dated: $P O G$ 1965, 97-99, no. 1, figs. 405-408; Schefold 1997, 88-89 fig. 22; Krumeich 1997, 71-89, esp. 72-78 for the Ostia herm. At any rate, a painted image of him seems to have been dedicated by his sons in the Parthenon: Paus. 1.1.2. A basic difference, however, may have existed between painted and sculptured portraits. Fuchs 1995, 74-75 believes that the lioness on the Akropolis (Paus. 1.23.2) is a commemorative statue of Leaina, the mistress of Aristogeiton, one of the Tyrantslayers; this story, repeated by several Roman sources (Plin. $H N$ 34.72; Plut. De garr. 8), is likely, however, to be an anecdote, and, at any rate, the woman would have been rep. resented in allegorical form, not by a true portrait.

${ }^{28}$ Ridgway 1984, 56. For additional bibliography, see also supra n. 4, especially now Krumeich 1997 . The very limited number of replicas of assured Perikles portraits (3), and the fact that the two inscribed herms, now in the Vatican and the British Museum, come from the same findspot-the Villa of Cassius, at Tivoli-may speak in terms of a Roman creation, since a portrait of Pheidias, obviously imaginary, was also recovered from the same villa (see Ridgway 1984, 63, ns. 44-45, for additional references). The head of Perikles now in Berlin, however, was allegedly found on Lesbos; although it repeats the same type as the other herms, it ends in a tenon for separate insertion. If this rendering was not ultimately meant for a herm (transporting the head alone, without a hermaic bust, perhaps from a copyists' workshop in Rome, would have involved considerably less weight), the Berlin head may have belonged to a draped or a cuirassed body. Should this be the case, the nakedness implied by the extant herms (with all concomitant speculation on possible heroizing features: cf. Hölscher 1975) would be misleading and irrelevant. Helpful comments in the same vein are made by Krumeich 1997 , 121-25. On the relative reliability of herm renderings for reconstructing full-scale statues, see also infra. 
traits of Anakreon - all of the same type - have also been thought to reproduce the sculpture on the Athenian citadel, ${ }^{29}$ although other images of the poet are known to have been erected elsewhere. Yet my concern here is not to prove or disprove such a provenance, but to determine a plausible date for the Copenhagen statue and the replicas of its head, regardless of attribution to a definite site.

Because it retains its full body, the Ny Carlsberg sculpture (fig. 5) has usually been the focus of attention in studies of Anakreon's portraits. Identification, however, rests on an inscribed herm from Trastevere, now in the Conservatori Museum, with folds of drapery on both shoulders. This arrangement seems to echo the full statue, yet another inscribed albeit headless herm - perhaps significantly, from the Athenian Agora-shows no such traces. It could be assumed that the herm in Athens copied the Akropolis monument, thus making a strong case against the Copenhagen and Trastevere pieces as reproductions of the image that Pausanias saw. Yet I believe that herm-makers in general were flexible in their renderings, at times including, at others eliminating, hints of clothing from their work. ${ }^{30}$ One more inscribed herm, also headless, cannot now be found, and a head in Berlin, said to be made for insertion into a statue, has a slanted cut of the left side that may indicate a tunic, once again raising the issue of the corresponding body. The remaining six items are heads, usually inserted on modern busts. All available replicas of the portrait type for which a provenance can be ascertained seem to come from Italy and to date from the Hadrianic or Early Antonine period, except for the head in the Louvre that may be as late as the third century. ${ }^{31}$ The headless Agora

\footnotetext{
29 This belief is shared by all commentators cited in the previous notes; others will be mentioned infra. The only exceptions are Campbell 1988, 31 n. 2, and Rosenmeyer 1992, 24, 28, 34. See also Ridgway 1984, 54-55, 63 ns. 40-43, with doubts on the traditional chronology. I had, however, accepted a mid-fifth century date in The Severe Style in Greek Sculpture (Princeton 1970) 71 no. 4.

30 Trastevere herm: $P O G$ 1965, no. 1. The Athenian herm (POG no. 11) is published $\rightarrow$ B.D. Meritt, "Greek Inscriptions," Hesperia 26 (1957) 89, no. 34, pl. 17. A telling example of herm-makers' practices is provided by the Sophokles types. Richter's Type II (POG 1965, 128-30) is the so-called Lateran Sophokles, after the full statue now in the Vatican ( $P O G$ 1965, no. 2, figs. 675-77). Her nos. 1 (an inscribed bust in the Vatican, figs. 678-79) and 3 (a herm in the Capitoline Museum with a 16th-century inscription, fig. 681) show the same head type, but have no traces of a mantle, despite the fully enveloped prototype. The Sophokles Type III $(P O G$ 1965, 130-31), although less securely identified, comprises two herms (no. 3, fig. 692; no. 5, figs. 693-95) with drapery on both shoulders but in different patterns, and one more bust (no. 6, figs. 705-707) with only the left shoulder covered
}

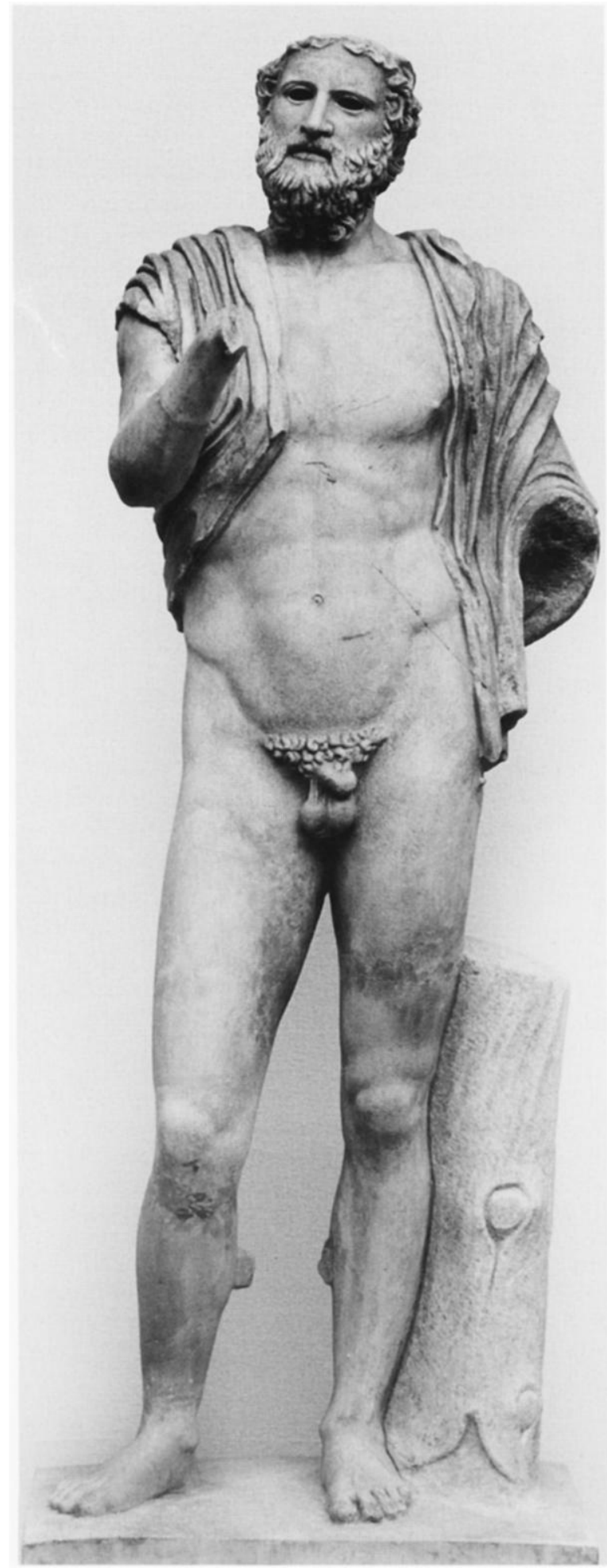

Fig. 5. Borghese Anakreon. Copenhagen, Ny Carlsberg Glyptotek, I.N. 491. (Photo courtesy Glyptotek)

${ }^{31}$ Head in the Louvre: $P O G$ 1965, no. 6 (Ma 656), unfinished, as I could verify in 1995; the chronological assessment is provided by $\mathbf{H}$. Lauter, Zur Chronologie römischer Kopien nach Originalen des V.Jahrhunderts v. Chr. (Bonn 1966) 114. The inscribed but headless herm, now lost, is $P O G$ 
herm-shaft is dated to the beginning of the second century A.D. on the basis of its letter forms.

One scholar has suggested an earlier date for the Copenhagen statue. This sculpture was found in 1835 in the villa of Bruttius Praesens, future father-in-law of Commodus, at Monte Calvo, in the Sabine Hills, near Rieti. ${ }^{32}$ The site is therefore sometimes cited as the Villa of the Bruttii, or simply as Monte Calvo. The residence was probably established in the mid. second century A.D., and some statuary carved spe cifically for its adornment. Other works (for instance, portraits of Antoninus Pius, Lucius Verus, and Marcus Aurelius) were obviously added later; a few pieces, however, could have been brought in from earlier contexts. The Anakreon, a Seated Poet in Hellenistic style (fig. 6), and a torso of a bearded divinity usually identified as Zeus or Asklepios-now all in Copenhagen - have been occasionally considered products of a Late Hellenistic/Late Republican workshop, after prototypes of various periods. Yet this suggestion has not found many adherents and the more generally accepted date (Late Hadrianic/midsecond century A.D.) appears more probable. ${ }^{33}$ After excavation, most of the statuary passed into the Borghese Collection, but some was eventually dispersed to various museums. The most famous pieces from that findspot are still cited with their "Borghese" appellation: not only the Anakreon and the Seated Poet in the Ny Carlsberg Glyptotek, but also the so-called Hera Borghese in the same museum, and the fa-

no. 10, the head in Berlin (for clear insertion into a separate body, as I verified in 1997) is no. 7 (figs. 277, 280). To recapitulate: the corpus of Anakreon's sculptural portraits consists of one full statue, three herms (of which two are headless), and seven heads, all after a single prototype.

32 This is the finding date given by all catalogues and discussions, but sculptures from the same location may have been unearthed somewhat earlier. Türr 1971, 44-45 states that the Muses from Monte Calvo were already mentioned in "BullInst 1829, 36." She also mentions (n. 143) that the layout of the villa was too damaged for a chronological assessment.

${ }^{33}$ The early chronology is suggested by Neudecker 1988,69 , with complete catalogue of finds on pp. 180-84, no. 35 with 47 individual entries. The Anakreon (Ny Carlsberg, I.N. 491) is no. 35.13, the Seated Poet (Ny Carlsberg, I.N. 1563) is 35.12, and the Zeus/Asklepios (Ny Carlsberg, I.N. 1425 ) is 35.14 (pl. 21.1). He assumes that these three pieces are earlier not only on the basis of workmanship that bespeaks a single workshop, but also because the Asklepios does not fit thematically with the other two, which were found together "in una specie di sala." Surprisingly, Zanker 1995, 146-49 calls the Seated Poet (identified by him as Alkaios) "a superb copy of the 1st century B.C." Yet the piece, technically, should go with the Anakreon, which, on the basis of the tree-trunk support, drill work, and other carv-

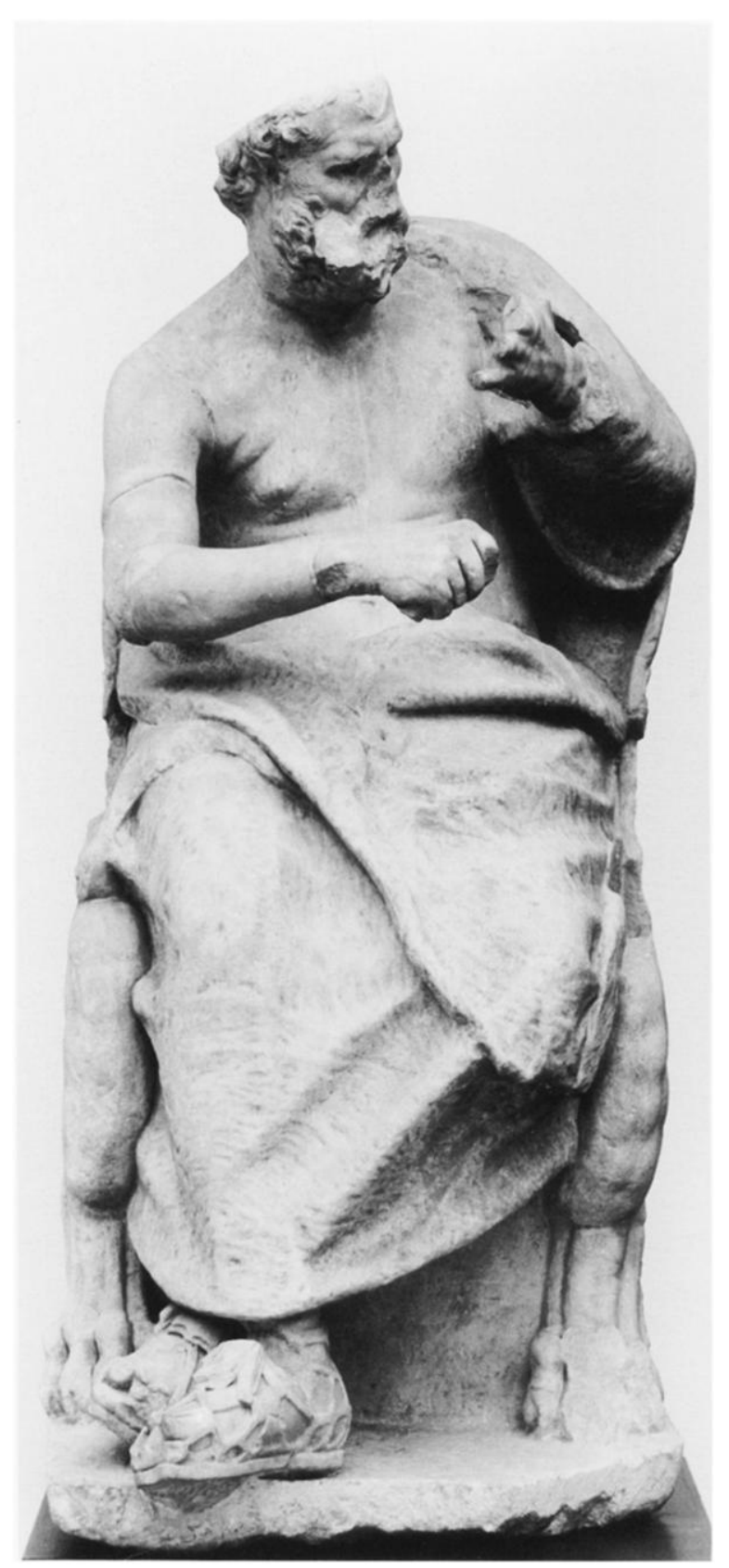

Fig. 6. Seated Poet. Copenhagen, Ny Carlsberg Glyptotek, I.N. 1563. (Photo courtesy Glyptotek)

ing details, seems more in keeping with an Imperial date.

On the villa at Monte Calvo, see also Türr 1971; and, briefly, C.C. Vermeule, Greek Sculpture and Roman Taste. The Purpose and Setting of Graeco-Roman Art in Italy and the Greek Imperial East (Ann Arbor 1977) 65. The most extensive ac count of the acquisitions of antiquities by the Borghese family is M. Moltesen, "From the Princely Collections of the Borghese Family to the Glyptotek of Carl Jacobsen," AnalRom 16 (1987) 187-203, with an appendix (pp. 200-201) on the Monte Calvo excavations (the Zeus/Asklepios is her fig. 15 on p. 199). 
mous Borghese Satyr (Marsyas?) still in the Villa Borghese in Rome. Some are now lost and are only known through the initial brief listing. ${ }^{34}$

From the very beginning, the Borghese Anakreon has been hailed as a replica of a famous bronze orig. inal and, after discovery of the Trastevere herm, connected with Pausanias's mention of the poet's statue on the Athenian Akropolis. Interpretations of his pose and meaning show, however, considerable variance. Noting the strong physique and the stable stance with both feet flat on the ground, right leg only slightly flexed and advanced, some commentators have read the image as "a naked, virile warrior, into whose hand a lyre has been put." Pausanias must have described it as indicative of drunkenness simply be cause he expected it to be so, given the conception of the poet current in his own time. ${ }^{35}$ Others have accepted the hint at inebriation but have seen it rather as poetic enthousiasmos, and the pose as typical for a lyre player. Emphasizing the way of wearing the chlaina, they have suggested that the statue stood for the pleasures of the symposion and love, even more than for the value of lyric poetry. ${ }^{36}$ Finally, the most recent interpretation, by Paul Zanker, has stressed the figure's infibulation, not as a practice typical of singers and musicians, but as a form of decorous restraint in an aged symposiast. ${ }^{37}$

This explanation, coming from an authoritative source, and within a book that examines ancient portraits as an expression of classical attitudes toward intellectuals, requires further discussion. Zanker describes the Copenhagen Anakreon's pose as that of

${ }^{34}$ Borghese Satyr: LIMC VI (1992) 368 no. 4, s.v. Marsyas (A. Weis); LIMC VIII (1997) 1130 no. 214, pl. 781, s.v. Silenoi (E. Simon); cf. Neudecker 1988, 181 no. 35.1, pl. 21.2. Borghese Hera (Ny Carlsberg, I.N. 1802): LIMC IV (1988) 671 no. 102, s.v. Hera (A. Kossatz-Deissmann); cf. A. Delivorrias, "Problèmes de conséquence méthodologique et d'ambiguïté iconographique," MEFRA 103 (1991) 129-57, esp. 150-57, fig. 34, with mention of other replicas (figs. 35-36) and discussion of possible identification (Aphrodite?). The pieces now lost or unrecognized include some headless statues of athletes and a complete cycle of Muses, of which only four can now be accounted for, purchased by the $\mathrm{Ny}$ Carlsberg Glyptotek in 1897: cf. Türr 1971.

${ }^{35}$ Poulsen 1931, with previous references. The quotation is from p. 13; cf. also p. 15: "a pattern of Attic manhood, a bearded hero who could take his place among the knights of the Parthenon frieze." Poulsen stresses, however, that this characterization is far from the essence of the true Anakreon, and considers the figure's infibulation to be the only feature "which is historically and humanly true." Richter, $P O G 1965,76$ repeats that early art historians mis. took the virile appearance of the sculpture for a portrait of the Spartan poet Tyrtaios. Cf. also Rosenmeyer 1992, 23 and n. 38, mentioning "heroic nudity." Pia G. Bilde sug. a slightly intoxicated singer, swinging as he plays the now missing barbiton. He therefore accepts that the statue shows him as a participant in a symposion rather than a poet as such, but a symposion of Perikles' times, rather than the jolly occasions of Anakreon's own life span. At the time of the Parthenon, Zanker argues, the practice of convivial drinking was becoming less common as a subject for vases, and Athens was acquiring a reputation for sobriety and excessive focus on athletics and warfare. Perikles, by setting up this type of image, would have shown Anakreon as a symposiast to imply that the activities associated with his poems still excited Athenian interest, but not in the decadent form of the tyrannical period - hence Anakreon's nudity, rather than his more traditional "foreign" attire of long chiton and himation; and infibulation, to convey that the singer (although elderly, as discreetly implied by the length of his beard and his full frame) was not the tipsy, lecherous old man suggested by his own verses but a model of proper enjoyment. Taken together with the Xanthippos portrayed as a warrior, the two statues would have represented the twin ideals of Athenian society according to Perikles' vision.

This seductive picture rests on two basic assumptions: that the Anakreon Borghese copies a fifthcentury original, and that this original stood on the Akropolis as part of a Periklean message, for a Periklean audience. Yet the very statue in Copenhagen was meant to speak primarily to its Roman sponsors, in the very different setting of a Roman villa. When

gests ( per ep.) that the tight wrapping of the chlamys is meant to add to the athletic appearance of the figure.

${ }^{36}$ E. Voutiras, Studien zu Interpretation und Stil griechischer Porträts des 5. und frühen 4. Jahrhunderts (Bonn 1980) 77-91. He compares the head of the Anakreon to that of the centaur on Parthenon South metope no. 2, which he considers inspired by the poet's portrait, but this is criticized by $\mathrm{L}$. Giuliani (review of Voutiras, in Gnomon 54 [1982] 54), who thinks both works reflect experimentation with types. The Greek scholar accepts a fifth-century date for the portrait's prototype, but considers the possibility that it was put up by a faction opposed to Perikles, the oligarchs, of which Kritias, Anakreon's admirer, was a representative. Voutiras's statement that Anakreon's poetry was no longer appreciated by the second century A.D. is refuted by Neudecker 1988 , n. 689, on the strength of Aulus Gellius and, we may add, the Anakreontea.

${ }^{37}$ Zanker 1995, 22-31. For the classical practice of infibulation (well attested for athletes) as used by Dionysiac artists, see Poulsen 1931, 15, who quotes a Roman poem (Priapea 77) in which Priapus compares his sexual restraint to that of a clusus citharoedus. Frel (supra n. 3) 14 cites the belief that chastity improved singers' voices (as well as athletes' performances). 
this second location is kept in mind, another picture may emerge.

As already mentioned, the Monte Calvo site contained other statuary, including the well-known Borghese Satyr - and he too is infibulated, in the same manner as the Anakreon. ${ }^{38}$ The creature was probably represented in the act of playing the double pipes, therefore as a musician as well, but his type of performance did not require singing and there fore "chastity" for a clearer voice. Moreover, ancient sources seem to advise the procedure for adolescents, not for mature individuals, and a chaste satyr would have carried humorous connotations that seem out of place in a Roman context also involving poets and Muses. ${ }^{39}$ Could it be that this peculiar arrangement was required by the villa owner, who had his own standards of modesty and decorum? Indeed, the Romans seem to have used infibulation primarily for propriety, and for protection of the genitals in ath letes; as a device to enforce abstinence it was certainly ineffectual, since the fibula or ligature could be removed at will.

It is regrettable that the penis is usually missing in statues that have come down to us from ancient times. Often inserted separately, the phallus broke off easily because of its exposed and fragile nature, and was frequently the object of playful (or religious?) vandalism, in Late Antiquity or in more recent cen-

\footnotetext{
38 There are different forms of infibulation (Lat. infibu

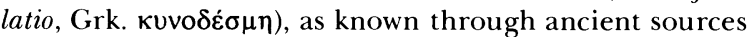
and visual representations. For a discussion, see $R E 9$ (1916) cols. 2543-48, s.v. Infibulatio (J. Jüthner); less useful, for my purposes, is W.E. Sweet, "Protection of the Genitals in Greek Athletics," AncW 11 (1985) 43-52, esp. 49 on the practice among revelers and satyrs (considered comical in the latter). Zanker 1995, 29 mentions other treatments of the subject; he stresses the mature appearance of symposiasts on vases approximately datable to 440 (cf. his fig. 18 on p. 30), for whom infibulation would be an expression of modesty, and the comic effect of infibulated satyrs.

39 The activity of the Borghese Satyr is suggested by other replicas of the same type that retain the mouthpiece for the pipes - hence the identification as Marsyas, possibly in contest with Apollo. The pose of the figure may represent a dance movement, but also the swaying of the piper. One replica of the Omphalos Apollo type, the socalled Choiseul-Gouffier statue in the British Museum, is also infibulated: cf. LIMC II (1984) 257-58 no. 599a, pl. 228, s.v. Apollon (O. Palagia). Attributes are missing, but because of his anatomical development, the god could be portrayed as an athlete, as well as an adolescent singer $(k i$. tharoidos), since he wears his hair long and braided; or the rendering may be due to the Roman owner's request. It would be useful to make a study of the replicas of this type
}

turies. Analysis of other male statues from Monte Calvo is equally unprofitable, because they are either lost or draped. It is, however, useful to consider the possible grouping of the Borghese Anakreon, to de rive additional information about its intended mean ing in its own context.

The identity of the Seated Poet (fig. 6) found within the same room is still debated. Although replicas of the head exist, no inscription remains to name him, and various suggestions have been made: Pindar, Alkaios, or even Archilochos, as preferred by Richter, although she admits that the Parian bard did not become as old as the individual portrayed by the Borghese statue. ${ }^{40}$ That he is a poet is shown by the traces of the plektron in his right hand; the left probably held the lyre, although the form of at tachment remains unclear. The style of the figure could be defined as Hellenistic Baroque: the face is highly modeled, the hands are dimpled, the anat omy is sagging, the garment wrapped around his legs is highly textured, and the twisted pose, on the high throne with lion- (or griffin-?) legs' front, is in keeping with a mid-second century date, by traditional reckoning. The sandals (trochades) with their obvious lingula seem more typically Roman, but copyists are known to have altered footwear at will.41

Mutatis mutandis, the Borghese Poet recalls the head of the wineskin carrier from Sperlonga, in

to determine whether the infibulation recurs in all of them or is a feature of this particular (Hadrianic?) copy. Regret tably, many have been restored or altered in modern times, if not before discovery.

40 POG 1965, 67-68, figs. 231-42; at least two of the heads wear an ivy wreath, absent in the Copenhagen stat ue, although a depression may suggest that it was added in metal. In October 1995 I examined the statue with a group of students from the Universities of Aarhus and Copenhagen, and doubts were expressed about the head be longing to the seated body. Indeed, a ring of modern plaster seems to separate the head from the neck (cf. Johansen 1992, fig. 2 on p. 138), but the color of the marble, the style, and the correspondence of details would confirm its pertinence. The mid portion of the right arm (although not the right hand and wrist) might also be questioned, al though Johansen 1992, 138 no. 57 ("Archilochos") does not list it as a modern repair. There is no doubt, however, that the figure was originally depicted playing the lyre, if not actually singing. Schefold 1997, 270 believes the statue copies the Pindar erected (ca. 180-170?) in the Athenian Agora, in front of the Royal Stoa and near the Temple of Ares (Paus. 1.8.5); cf. his fig. 147 for a replica of the head.

${ }^{41}$ Cf. K.D. Morrow, Greek Footwear and the Dating of Sculpture (Madison 1985) 118-20; cf. 171-73 for the practices of copyists. 
the group of the Blinding of Polyphemos; or even the pilot in the Skylla episode, where similarity may be enhanced by technique, because of the separately added cranial calotte in both cases. To be sure, these comparisons will not lead to a clearer chronological assessment, given the controversy still raging over the sculptures from the famous grotto, but they are important in determining a possible stylistic tradition in Imperial workshops active in or near Rome. ${ }^{42}$ I would, however, note here the distinctive way in which the beard hugs the neck of both the Sperlonga wineskin carrier and the Borghese Poet. An analogous rendering appears on the Borghese Anakreon, although its general style is obviously quite different. Yet technical features make it clear that the statues of the two poets now in the Ny Carlsberg came from the same studio: the separately carved calotte, the use of the drill within the hair locks, and especially the inserted eyes.

This third feature is also found in the so-called Asklepios, although, once again, its general appearance differs. The identification is based on the advanced position of the right arm and hand, palm down, that supposedly rested on a snake, after the chryselephantine image made by Thrasymedes of Paros for the Asklepieion at Epidauros, in the early fourth century. As already mentioned, its presence together with two poets had seemed incongruous, but the discrepancy would be eliminated if the majestic figure were identified with Zeus, father of the

\footnotetext{
${ }^{42}$ Sperlonga wineskin carrier: B. Conticello and B. Andreae, "Die Skulpturen von Sperlonga," AntP 14 (1974) pls. 9, 12; pilot: pl. 32. On the dating controversy, most recently, see N. Himmelmann, Sperlonga: Die homerischen Gruppen und ihre Bildquellen (Nordrhein-Westfälische Akademie der Wissenschaften, Vortrage G 340, Opladen 1995/1996), and C. Kunze, "Zur Datierung des Laokoon und der Skyllagruppe aus Sperlonga," JdI 111 (1996) 139-223.

${ }^{43}$ On the Zeus/Asklepios, see supra n. 33; add LIMC II (1984) 871 no. 44, pl. 636, s.v. Asklepios (said to be from Tusculum), dated "Antonine Period?" (B. Holtzmann). Only the naked torso down to the lower abdomen remains; the head, which once wore a metal wreath, is broken along an oblique surface that eliminates the left upper part of the face, but the (once inserted) right eye is still discernible.

For the Apotheosis of Homer Relief, see LIMC VII (1994) 1004 no. 266, pl. 723, s.v. Mousa, Mousai (L. Faedo).

${ }^{44}$ The inserted eyes may have been meant to give a divine cast to the figures. The Anakreon's height is given as $2.15 \mathrm{~m}$ with plinth, $1.98 \mathrm{~m}$ without, by Poulsen 1931, $4 \mathrm{n}$. 1 ; but as $1.90 \mathrm{~m}$ by Johansen 1992,18 , with $0.16 \mathrm{~m}$ for the plinth - at any rate, slightly over life size. Johansen also gives $1.63 \mathrm{~m}$ as the height of the Seated Poet. It is hard to compare the heights of the Seated Poet's and the
}

Muses, as he appears on the relief from Bovillae known as the "Apotheosis of Homer." ${ }^{33}$ We thus would have a display of three statues, apparently representative in turn of the Early Classical, the High Classical, and the Hellenistic style, obviously linked by the magnetic effect of the inserted eyes and by the approximate scale, although the Seated Poet gives the impression of being larger than the Anakreon, and the "Asklepios" may have been heroic in size, as appropriate for a divinity. ${ }^{44}$

What else can be grouped with these figures? Türr mentions the fragment of a hand with plektron that, in her opinion, belonged to a third poet. Neudecker attributes it instead to an Apollo, now lost, but implied by the recovery of a tripod, which he would therefore group with the Borghese Marsyas. Finally, a group of Muses was also found, as already mentioned, but they, as well as the Marsyas, seem differentiated by their solid (i.e., not inserted) eyes, heads in a single piece, and, possibly, a findspot elsewhere on the premises. To be sure, a group of Muses and poets, perhaps in the presence of Apollo and Zeus, would not be unusual in a luxurious villa of the midsecond century A.D., but the point cannot be proved. The style of the Borghese Marsyas would take it back to a prototype of the second century B.C.; that of the Muses is more eclectic, and Türr likes to see them as Hadrianic creations, but other commentators date them variously within the second century B.C., accepting only the (perhaps random) groupings as $\mathrm{Ha}$ -

\footnotetext{
Anakreon's heads, since in both cases the calotte is missing, but they appear to be approximately on the same scale; that the Seated Poet may seem larger is probably due to the pose and the ample costume.

The Zeus/Asklepios torso is $1.12 \mathrm{~m}$ as preserved: F. Poulsen, Catalogue of Ancient Sculpture in the Ny Carlsberg Glyptotek (Copenhagen 1951) 86-87, no. 90. This source mentions a provenance from Tusculum but adds, in the bibliography, G. Lippold's opinion (Kopien und Umbildungen griechischer Statuen [Munich 1923] 267 n. 74) that the Asklepios is identical to an item from Monte Calvo - as now confirmed by Moltesen's investigation (supra n. 33). Poulsen assumes that the unfinished state of the back of the head and torso implies that the total image of Asklepios was akrolithic, the naked parts to be inserted in drapery of gilded bronze. This technique may have influenced the theory that the piece copied the chryselephantine Asklepios in Epidauros: B. Krause, "Zum Asklepios-Kultbild des Thrasymedes in Epidauros," $A A$ 1972, 240-57, with detailed views of the torso in Copenhagen as figs. 1-11. It seems to me, however, that the working of the back of the piece is compatible with a setting on a throne and in a niche, from which the "Asklepios" might have supervised the activity of the poets and/or the Muses.
} 
drianic or later. ${ }^{45}$ In brief, as we would have expected, the decoration of the Monte Calvo villa seems to have been highly eclectic, based on the pertinence of the subject matter, rather than on stylistic coherence or connection with famous masters.

\section{LETTING THE ANAKREON BORGHESE SPEAK FOR ITSELF}

The Roman context, although useful for certain details, is not likely to give us a clearer indication of the time when the original image of Anakreon was made. We should therefore look at the full statue itself, to see whether its style - aside from any consideration about Pausanias's mention - is in keeping with a date around 440 , as traditionally assumed. ${ }^{46}$

The way in which the Borghese Anakreon wears

${ }^{45}$ See Türr 1971, for suggestion of a third poet; Neu decker 1988 lists the now lost tripod as his cat. no. 35.15; cf. his p. 69, where the Marsyas and Apollo, in conjunction with the poets, are tentatively taken as part of a program representing divine, mythological, and human musicians. The Muses in Copenhagen are Neudecker 1988, no. 35.3-6; a Muse with a nebris (his no. 35.7), also in the Ny Carls. berg, is of uncertain provenance. On the Muses in general, see Türr 1971 (specifically, pls. 2, 10, 12.2, 17.1 for the Monte Calvo Muses; pl. 31.2 for the Muse with nebris); her theory of Hadrianic creation has not been widely supported. Cf. LIMC VII (1994) 1019 no. 58, pl. 732, s.v. Mousa, Mousai/ Musae (J. Lancha), for three of the Monte Calvo Muses in Copenhagen, considered Roman copies of the end of the second century A.D.; see pp. 1027-28 for the popular. ity of groups of Muses and poets beginning in the late first century A.D. and widely diffused in luxurious villas during the second century. A similar chronology, which takes the replicas back to prototypes variously dated to the third and second centuries B.C., is advocated by Faedo (supra n. 43) 992 no. 169; 993 no. 175, pl. 716 (Muse with nebris); 996 no. 201 (Muse with Herakles mask; cf. LIMC IV [1988] 744 no. 268, pl. 462, s.v. Herakles [O. Palagia]). The Muses in Copenhagen are said to represent Polyhymnia, Klio, and Melpomene. All three from Monte Calvo wear a similar wreath of flowers that links the figures, even if each echoes a prototype of different date. It has been pointed out that meaning appears more important than chronological co herence to Roman groupings of statuary in Greek styles; see, e.g., C.M. Edwards, "A Complex of Copies at Ancient Corinth," AJA 97 (1993) 300 (abstract).

${ }^{46}$ Even within the Classical dating some variation can be noted: Poulsen 1931, 10 placed the Borghese Anakreon in the decade 460-450. So did Frel (supra n. 3) 15, caption to fig. 36. Dörig 1977, 28 found the Anakreon's style ap. proximately 20 years later than that of the "Poseidon" Borghese (on which see infra), whose prototype he dated to 470-460. Voutiras (supra n. 36) championed a date before the Parthenon south metopes, since he assumed that the centaur of S 2 imitated the Anakreon. Hafner (supra $n$. 4) advocated a terminus ante quem of 438 , because he saw the Anakreon reflected in the shield of Athena Parthenos, presumably completed by that date. Richter, $P O G 1965$, mentioned a date around 440, which I accepted in Severe its chlaina is unusual: the shawl-like garment hangs in front of the left shoulder, crosses the back diagonally to below the right armpit, and is then flung upward over the right shoulder to end in a vertical swag down the back. Chlainai draped symmetrically over both shoulders are more common, for instance, in Archaic representations of Hermes, and are particularly popular on figures of symposiasts, but the fashion seems to decline after the end of the Archaic period. The specific arrangement on the Anakreon, however, is found twice again: on a Greek originalthe Oinomaos from the east pediment of the Temple of Zeus at Olympia (fig. 7)-and on a headless Roman figure, variously called the Borghese Poseidon or Warrior (figs. 8-9). ${ }^{47}$

This second sculpture owes its nickname to the fact

Style (cf. supra n. 29). She is also followed by Hölscher 1975, 191; Johansen 1992, 18; and Rosenmeyer 1992, 28 - cf. her n. 45 on p. 27: "One of the few well-preserved, identifiable fifth-century portraits, another tribute to the popularity of Anacreon." Zanker 1995, 24 gives a general attribution to the Pheidian circle, as accepted by most commentators cited above. See also H.A. Shapiro, "Democracy and Imperialism. The Panathenaia in the Age of Perikles," in J. Neils ed., Worshipping Athena. Panathenaia and Parthenon (Madison 1996) 215-25, esp. 218-19; he follows the theories of Hölscher 1975 and Zanker 1995, accepts the Anakreon and the Xanthippos as connected with those around Pe. rikles himself, and sees the poet "as a model symposiast" and "as a role-model for the musicians who competed at the Panathenaia and the poets whose works they performed."

${ }^{47}$ A Hermes with symmetrical chlaina appears, e.g., on the west frieze of the Siphnian Treasury at Delphi: LIMC V (1990) 324 no. 441, pl. 236, s.v. Hermes (G. Siebert); see also passim for representations on vases, although the god is usually shown with a chitoniskos below the chlaina. For symposiasts wearing only the chlaina, see, e.g., the red-figure lekythos in Syracuse, by the Gales Painter ( $\left.A R V^{2} 36.2\right)$, often cited because it includes a figure labeled Anakreon; Price 1990, pl. 3b, here fig 1. After the Archaic period, the chlaina appears worn asymmetrically pinned on one shoulder and is indistinguishable from the chlamys. The Archaic symmetrical draping is found again on Archaistic figures.

I repeat here the term chlaina used by most commen. tators on the Anakreon, but M. Bieber (Griechische Kleidung [Berlin 1928]; Entwicklungsgeschichte der griechischen Tracht, ${ }^{2}$ revised by F. Eckstein [Berlin 1967]) describes that garment as heavy and long, indistinguishable from the himation, and defines the chlanis as a finer and less full mantle, corre sponding to the Etruscan/Roman laena. For both attires, however, the popularity of the symmetrical arrangement seems to end with the early fifth century. The scarflike ar. rangement is not properly considered in either publication.

The Olympia Oinomaos and the Borghese "Poseidon" are illustrated in Poulsen 1931 (figs. 4 and 6-7, respectively; the "Poseidon" with the unrelated head of Trajanus Decius once placed on it) and in Dörig 1977 (figs. 48, 50, 54-57; much better photographs). For the "Poseidon," see also Fuchs 1995, figs. 3, headless, and 4-5, with the alien head. 


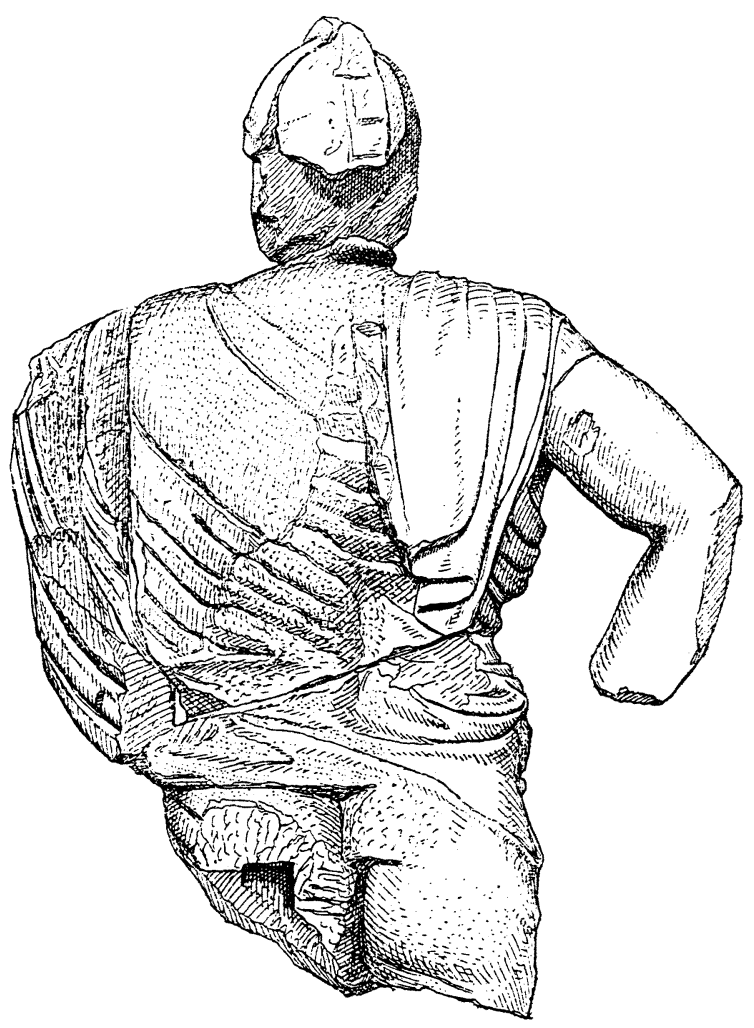

Fig. 7. Oinomaos, east pediment of the Temple of Zeus, Olympia. Drawing of back. (After G. Treu, Olympia III [Berlin 1897] 50 fig. 55)

that for 300 years it stood, outdoors, near the Casino Borghese, before being removed to the Museo Nuovo Capitolino (inv. 1389). Its provenance is unknown, but it was set up in the villa grounds by Pietro Bernini and it is mentioned by 17 th-century sources. It was at first considered a Zeus hurling a thunderbolt, a Poseidon carrying a trident, or a warrior brandishing a spear. When its resemblance to both the Oinomaos and the Anakreon was noted, it was more specifically suggested as a copy of the Xanthippos seen by Pausanias on the Akropolis, or of the Agamemnon in the group of Achaian heroes made by the Aiginetan Onatas for Olympia, or of the Poseidon dedicated at the Isthmos by the Greeks victorious at Plataia. ${ }^{48}$

${ }^{48}$ Xanthippos: Poulsen 1931, on the basis of the alleg. edly close measurements with the Anakreon (cf. his p. 10 n. 4); note, however, that the long exposure to the weather has considerably damaged the surface of the Borghese stat. ue. Agamemnon by Onatas: Dörig 1977, because of its pre sumed resemblance to other works that he attributes to the same master; he would date the Borghese statue before the Olympia pediments, ca. 470-460, and discounts its similarity to the Anakreon (p. 28). Poseidon at the Isthmos:

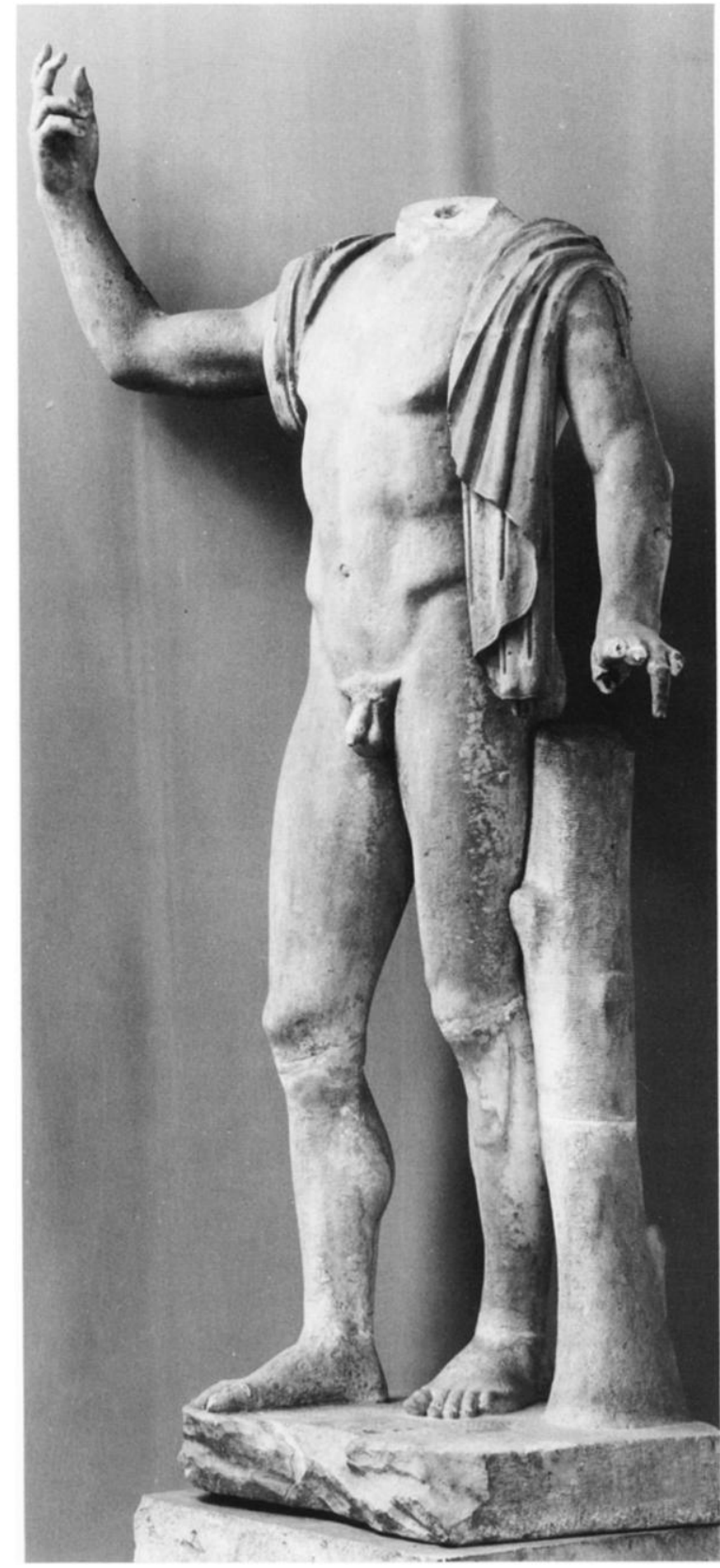

Fig. 8. Borghese Poseidon, Rome, Museo Nuovo Capitolino, inv. no. 1389; three-quarter view. (Photo Deutsches Archäologisches Institut, Rome, neg. no. 68.3463)

Fuchs 1995, because of a plaster cast from Begram and a terracotta lamp from the Athenian Agora, showing a comparable Poseidon near a lion and an altar; he would date the original to $475-470$.

The "Poseidon" cannot be another, unrecognized copy of the Anakreon, because its arms were in a different position approximating that of the modern restorations, as shown by the breaks and the extant drapery. 


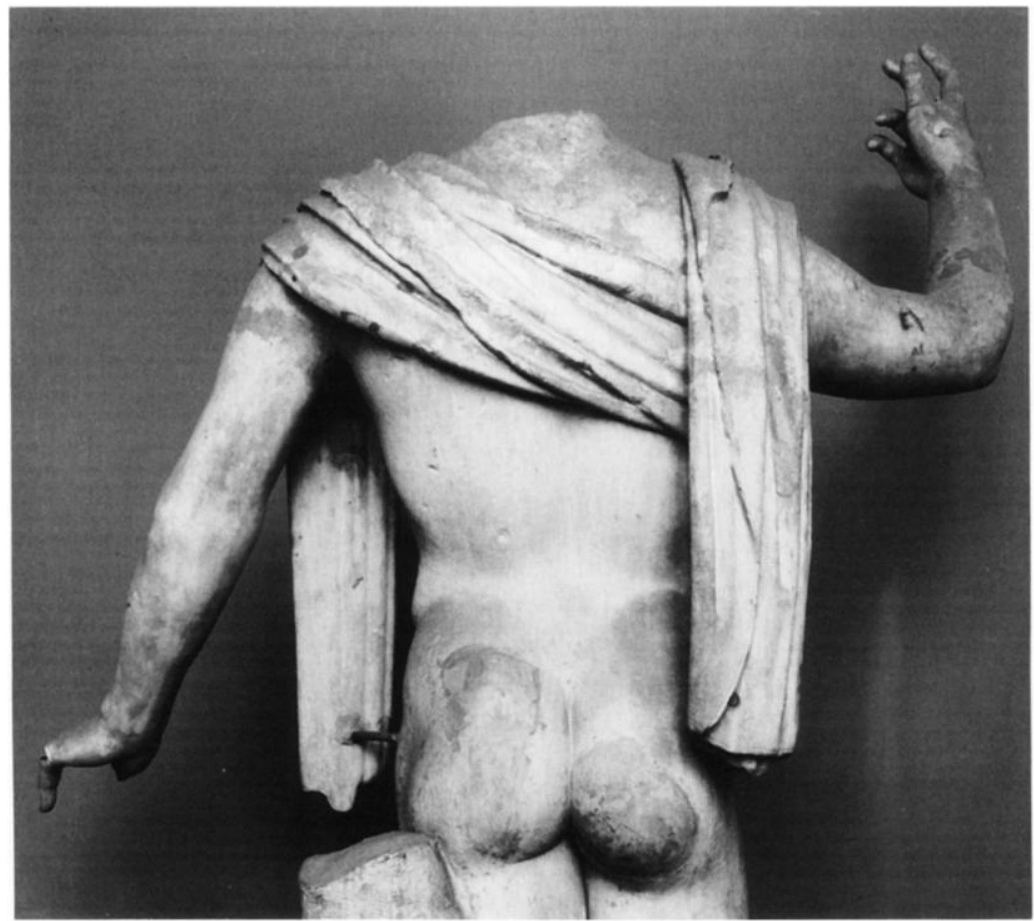

Fig. 9. Borghese Poseidon, inv. no. 1389; rear view. (Photo Deutsches Archäologisches Institut, Rome, neg. no. 68.3464)

It is difficult, without detailed measurements, to judge how close the Anakreon and the Borghese "Poseidon" really are. ${ }^{49}$ The latter, in its indoor setting, is imposing but shows minor differences, especially in the stance: its feet are closer together, and give the impression that the figure is stepping forward. In addition, its torso seems dryer (because of weathering?), and it is more exposed, less covered by cling. ing drapery; its pubic hair has the Late Archaic shape, with a slight peak in the center, whereas the Anakreon shows a straight line of well-ordered curls, closer to the pubic rendering of the Oinomaos. The Anakreon's folds, adhering to his body, are also more

${ }^{49}$ Poulsen 1931 gives only internal measurements. The total height of the statue is listed as $1.80 \mathrm{~m}$ without plinth (1.93 m with it): Helbig 4 II (1966) 540-41, no. 1767 (H. von Steuben). It is, however, headless, and both lower legs were probably restored. Other restorations involve the arms and the ends of the chlaina, which on the left side should have extended to the thigh, as indicated by a remaining strut. This arrangement may have been dictated by the desire to anchor the loose marble tip to prevent breakage. Figuring an additional $0.30 \mathrm{~m}$ for the missing head and neck, the total height of the figure might have been ca. $2.10 \mathrm{~m}$, therefore taller than the Anakreon. The correspondence of inner dimensions noted by Poulsen 1931 seems thus closely reminiscent of the Olympia sculptures, if not directly of the Oinomaos, whose chlaina extends to the right hip and thigh. The pedimental figure contrasts with both the Anakreon and the Borghese "Po. seidon" in that its stance is reversed, with the left leg forward and slightly flexed, the left hip higher because of the weight leg on that side; but the mirrorimage stance is found on the Pelops from the same gable..$^{50}$ In brief, all three statues - the Oinomaos, the Anakreon, and the Borghese "Poseidon"-show both similarities and differences, as one would expect from an original and its copies and adaptations; the one striking element is the peculiar arrange-

all the more striking. By comparison, the Oinomaos from Olympia, before the addition of the extant leg fragments, was calculated to have had an original height of ca. 2.95 $\mathrm{m}$ including plinth $(0.09 \mathrm{~m})$, sandals, and helmet crest: $\mathrm{G}$. Treu, Olympia III: Die Bildwerke in Stein und Thon (Berlin 1897) 50 (figure I). This statue is therefore considerably taller than either of the Roman "copies." More modern measurements are not likely to alter considerably this difference, given the Oinomaos's position within the gable.

${ }^{50}$ For a convenient illustration of the central sculptures of the east pediment, see A. Stewart, Greek Sculpture. An Exploration (New Haven 1990) fig. 264. 
ment of the chlaina, which was virtually invisible over the back of the pedimental figure.

It seems remarkable that the Anakreon should be given a garment that was no longer worn at all, or at least in this fashion, by Periklean times, if indeed the statesman wanted to make a point about contemporary symposia, as advocated by Zanker. The long chiton and himation shown on red-figure vases (including those inscribed with Anakreon's name) might have been considered "foreign" and symbols of decadent fashions, yet they were also typically Ionian, and are described as such by Aristophanes (Thesm. 159-63) with specific reference to Alkaios, Anakreon, and Ibykos: they are mitrophoroi and elkechitonoiwearing the wide band, low on the forehead, that is partly preserved in the Borghese Anakreon, and trailing their long chiton. If the Anakreontic vases have been correctly interpreted as depictions of the typical Ionic poet, rather than of Anakreon specifically, this is the image that the mid-fifth century Athenian would have carried in his mind, whether he knew the real Anakreon or not. ${ }^{51}$

Yet the Anakreontic vases have been read as parodies, just as Aristophanes seems to be poking fun at the luxurious outfit of the Ionic poets. Even Anakreon himself has been thought to hint at disapproval for effeminate garb, given his verses about Artemon periphoretos, who went from rags to riches. Yet this often-cited poem has also been interpreted in a different vein, its criticism pointed at the passive rather than the active sex role played by Artemon in his earlier life. Nothing, moreover, is said in it about

\footnotetext{
${ }^{51}$ For the Aristophanic description, see Papaspyridi Karouzou (supra n. 16), and cf. Price 1990, 169-70, who relates various interpretations of the verses.

In my comments, I continue to refer to Athens and the Athenians solely because the Borghese Anakreon has been so consistently connected stylistically with the Periklean circle, but, if my alternative scenario is followed, this work could easily have been created elsewhere. See infra.

52 The poem about Artemon is cited in Ath. Scholars at Dinner 12.533f; cf. Campbell 1988, 74-77, no. 388. The term "periphoretos" occurs in other verses, also cited in Ath. 12.533e-f (Campbell 1988, 64-65, no. 372). For the rolereversal interpretation, $\rightarrow$ C. Brown, "From Rags to Riches: Anacreon's Artemon," Phoenix 37 (1983) 1-15, with references to previous debate. Brown makes the important point that Anakreon's oeuvre, usually considered to be only about love and pleasure, contains also a great deal of invective, of which this poem would be an example. Cf. also Price 1990, 171. The Anakreontic vases, however, show other ele ments of attire besides chiton and himation; the sakkos or turban and the parasol are more typically feminine and
}

a specific dress but only about an ivory parasol and a carriage. ${ }^{52}$

If the Athenians of the Parthenon time disapproved of anything connected with the tyrants and foreign customs, they had only to look at the Parthenon frieze to see a contemporary rendering of elderly men, perhaps poets themselves: on the north side of the temple, a group of mature, bearded citizens have at times been interpreted as the rhapsodes who recited the Homeric poems; they wear a long himation that covers up their lower body and the left shoulder, leaving only the right portion of their chest bare. In front of them musicians carrying $\mathrm{ki}$. tharai are more heavily dressed in long chiton and himation - therefore in the kind of attire that was supposedly parodied on the vases. I find it, moreover, hard to believe that Periklean Athenians would have tried to discount Ionic allusions just at the time when they were emphasizing their autochthony and Ionic identity. .53

The Borghese Anakreon (fig. 5) looks quite different from the Parthenonian men: his hair seems shorter, with mannered wavelets across the forehead. The men on the frieze have fuller hair, especially over the temples and forehead, and at least one of them (slab N X, figure 41) sports the old-fashioned braids crossing over the nape. Their beards are also longer and project distinctly, whereas Anakreon's beard seems peculiarly short in front and clinging to the throat. To be sure, the upward tilting of the head could account for this feature, which recurs in some of the individual heads of the type, but

contrast with the excessively long, probably false, beards. Boardman (supra n. 16) 69 places specific emphasis on Artemon's parasol, on which see also Delavaud-Roux (supra $\mathrm{n}$. 16), with the same interpretation of parody in the use of feminine accessories.

${ }^{53}$ For the elderly men and musicians on the Parthenon north frieze, see, e.g., I. Jenkins, The Parthenon Frieze (London 1994) 86-87, slabs VII-X, figures 24-43; figure 38 on slab $\mathrm{X}$ seems in the act of crowning himself, perhaps as the victorious rhapsode in the competition. A correspond. ing arrangement occurs on the south side, although less well preserved: p. 69, slabs XXXVI-XXXVII, figures 93-107. For the practice of Homeric or epic recitation at the Pana. thenaia, see, e.g., H.A. Shapiro, "Musikoi Agones: Music and Poetry at the Panathenaia," in J. Neils ed., Goddess and Polis. The Panathenaic Festival in Ancient Athens (Princeton 1992) 53-75, esp. 72, for the fifth century. For the ideological situation, $\rightarrow$ W.R. Connor, "The Ionian Era of Athenian Civic Identity," ProcPhilSoc 137 (1993) 194-206, esp. 204-206 on autochthony. 
the Seated Poet also from Monte Calvo shows a comparable rendering, despite his lowered head. Finally, the Anakreon's head looks somewhat small in proportion to the elongated torso and the wide shoulders, and his stance is too unstable for the years around 440 that were beginning to feel the impact of the Polykleitan theories. In brief, the statue seems to me Severizing rather than truly Classical or Severe. ${ }^{54}$

The following scenario is, to be sure, hypothetical and thoroughly unprovable, yet it can be considered, once the association of the Anakreon type with the Akropolis statue, or at least with the Periklean circle, is discounted. As we have seen, Anakreon's oeuvre was compiled and the first treatise on him was written during the fourth century. A statue of the poet could well have been desired at that time, perhaps in Athens itself, which was seeing a revival of interest in intellectuals of the past, and set up the statues of the three major fifth-century playwrights in the Theater of Dionysos. Coincidentally, repairs were also being made to the Temple of Zeus at Olympia and its pedimental sculptures, including some replacement figures on the west gable. To portray a poet who had lived at the end of the Archaic period, inspiration might have been sought from famous statues that represented the style current approximately a decade or two later, and the Oinomaos could have been copied more or less faithfully, given the possibility of a close inspection, and perhaps even of repairs to the very figure.

Alternatively, the Hellenistic period may have provided the necessary impetus: the Alexandrian scholars were working with Anakreon's poems, imitations of them were being produced and passed as authentically Anakreontic, and repairs were once again needed to the Olympia gables. This was also the time

\footnotetext{
${ }^{54}$ I had already expressed similar ideas in Ridgway 1984: cf. supra $n$. 29. They were strengthened by my second visit to Copenhagen, in 1995. Zanker 1995, 24 admits that the stance looks unstable from a side view. For the issue of Severizing, see Ridgway (supra n. 29) 130-45, and, more recently, my "Lo stile severo. Lo stato della questione," in N. Bonacasa ed., Lo stile severo in Grecia e in Occidente. Aspetti e problemi (Studi e materiali, Istituto di Archeologia, Università di Palermo, no. 9, Rome 1995) 35-42.

55 The Hellenistic period is also the time when some smaller-scale replicas of the Athena Parthenos were produced, which may have involved a closer look at her shield. If the resemblance noted by some scholars between the so-called Kapaneos and the Anakreon truly exists (and we only have the "Neo-Attic" reliefs to compare), influences
}

when other images of Anakreon were being erected, if we can believe the realistic description of Leonidas's epigram. A more "epic" formula could have been followed for a specific customer, with a hint of old age in the peculiar beard, perhaps thinner to suggest the poet's advanced years. The second-first centuries B.C. were also the time when statues of intellectuals were becoming increasingly popular everywhere, and when revivals of the Severe style were current. ${ }^{55}$

Finally, we should consider the possibility that the Borghese Anakreon was created specifically for the Monte Calvo villa. This full-scale statue is at present unique, no other replica of the full body being known. ${ }^{56}$ To be sure, Romans were primarily interested in heads, which for them embodied the real essence of the individual, as contrasted with the Greek conception of total characterization, comprising body language and ethos. Perhaps a portrait head of Anakreon from either the fourth or the second century B.C. was already known in copyists' circles, but the Monte Calvo program demanded a full-scale figure. A workshop that may already have been familiar with the Borghese "Poseidon" and the Olympia sculptures could have used that body type to represent a period different from that of the Seated Poet and the Zeus. I admit, however, that this antiquarian/ historical knowledge seems alien to the Roman vision of Greek art. On the other hand, the dates of all the extant replicas of Anakreon's portrait seem to fall after the Monte Calvo statue and may be dependent on it, rather than vice versa; distribution, as far as ascertainable, is limited to Rome and environs. The first image of a "virile" Anakreon may well have been made ex novo for a mid-second century A.D. Roman who was not satisfied with the Hellenistic versions of the drunken poet. Or, in more practical

may well have gone from the shield relief to the portrait rather than vice versa.

${ }^{56}$ Contrast the case of Demothenes - whose distinctive body is never used for other portrait types and obviously reproduces the original by Polyeuktos, although only three replicas of it are known at present (as against over 50 heads or busts) - with that of other individuals whose portrait can be joined to stock (formulaic) bodies, thus suggesting that no full image of them existed: B.S. Ridgway, "Response," to R.R.R. Smith and P. Zanker, in part 3 of A.W. Bulloch et al. eds., Images and Ideologies: Self-Definition in the Hellenistic World (Berkeley 1993) 231-41, esp. 235-36. On the uncertain evidence of the Anakreon herms for a mantled body, see supra n. 30 . 
terms, the sculptors furnishing the Monte Calvo villa did not have such Hellenistic versions available in their repertoire and had recourse to the Olympia prototype.

To me, this seems the essential point. The Borghese Anakreon could not have been made without a knowledge of the Oinomaos, given the peculiar wrapping of the chlaina. And the back of the Olympia figure would not have been seen after its installation, until repairs provided access to the gable, in the fourth century or later. To be sure, the draping of its mantle could have been understood even from the front, but not easily, and especially at a considerable distance. ${ }^{57}$ Accepting the Anakreon's body as such an imitation, however, eliminates most of the grounds for the stylistic dating that has traditionally been used to assess the Ny Carlsberg statue.

It is becoming increasingly clear, I believe, that a purely formal analysis of extant ancient sculptures no longer suffices. Not only are works of the Roman period interpreted with greater caution than before, but even Greek "originals" are now being subjected to the same scrutiny, in the realization that styles once thought typical of specific time spans could instead coexist or be revived for iconographic purposes. In addition, the work of Carol Mattusch on ancient bronzes has stressed the potential for repetition inherent in the medium itself, and its farreaching consequences for a history of Greek art based on the premises of sequential stylistic devel. opment and the uniqueness of artistic creation. ${ }^{58}$ It is against this wider background and with a new skepticism about the overinterpretation of classical written sources that the case of the Borghese Anakreon has to be judged.

\section{DEPARTMENT OF CLASSICAL AND \\ NEAR EASTERN ARCHAEOLOGY \\ BRYN MAWR COLLEGE \\ BRYN MAWR, PENNSYLVANIA 19010 \\ BRIDGWAY@BRYNMAWR.EDU}

\footnotetext{
${ }_{57}$ That the crossing folds on Oinomaos's back were fully worked out in their basic course suggests that its sculptor meant to ensure the accuracy of the effect from the front. Back views of both the Borghese "Poseidon" and the Oinomaos are shown in Dörig 1977, figs. 54-55.

${ }^{58}$ C.C. Mattusch, Classical Bronzes: The Art and Craft of Greek and Roman Statuary (Ithaca 1996), esp. 141-51. Her book is well summarized and reviewed by J.M. Hurwit, "The Death of the Sculptor?" AJA 101 (1997) 589-90. See also B.S. Ridgway, "Defining the Issue: The Greek Period," in Retaining the Original (Studies in the History of Art 20, Na-
}

\section{Appendix}

\section{Anakreon, Artemon, and Polykleitos}

In studying the complexities of the sources on Anakreon and his life, it has occurred to me that one more ancient passage might be revised in light of our current knowledge. Pliny, HN 34.56, lists among the works attributed to Polykleitos a single portrait: "Artemona, qui periphoretos appellatus est." The name Artemon is relatively common, and several individuals by this name are known, some of them intellectuals. At least three of them from the second century B.C. are cited in $O C D^{3} 184-85$, s.v. Artemon (1-2: M.B. Trapp; 3: J. Denniston, K.J. Dover, M.B. Trapp), and during the fifth century an Artemon was a military engineer who constructed siege engines for Perikles at the time of the Athenian attack on Samos. Plutarch (Per. 27.3-4) gives Ephoros (a fourthcentury historian) as his source for this information, and for the detail that this Artemon was lame and had to be carried in a litter, thus acquiring the nickname "periphoretos." Even in antiquity, however, this identification was disputed, in that (Plutarch adds) Herakleides of Pontos (a writer and philosopher, ca. 390-310) connected the nickname with Anakreon's verses and a man of dissolute character who lived several generations before the Samian war. ${ }^{59}$ This chronological discrepancy is not resolved by Plutarch, who was not concerned with Polykleitan statues, and thus did not express his opinion, but the point is of some interest to modern studies.

The recent spate of publications on Polykleitos has either ignored the Plinian mention, or has suggested that this single portrait attributed to the master would have looked somewhat idealized, in the manner of the Riace Warriors. One scholar in particular believes that Riace B is connected with this specific Polykleitan statue, in that its stance shows the elements of the "Canon." He has also argued that the Amazon attributed to the same master, and part of the Ephesian dedication, commemorates that

tional Gallery, Washington, D.C., 1989) 13-26; and Ridg. way 1997 (supra n. 2) 365-67, and passim.

${ }^{59}$ Thuc. 1.115-17 relates the events at Samos more or less along the same lines as Plutarch's later account, but does not mention siege engines nor Artemon. The name is not epigraphically attested on Samos during the fifth century. In Athens it occurs 138 times (114 certainly Athenians, the remainder probably so), but none of them is earlier than the fourth century and most belong to the Hellenistic and Roman Imperial periods: Lexicon (supra n. 12) 66-67, s.v. Artemon. 
same Samian war, and that the date of both sculptures should therefore fall around 440/39. ${ }^{60}$

A philological study concerned with the Anakreontic Artemon has made a different suggestion: that the Athenian popularity of the Artemon verses was due to their being later attached to another Arte mon. Aristophanes (Ach. 850) makes a play on words suggestive of Anakreon's Artemon, by calling another Artemon periponeros ( $\pi \varepsilon \rho ı \pi o ́ v \eta \rho o \varsigma)$. Therefore C. Brown believes that, if Ephoros was correct in stating that the Periklean engineer was lame, the latter "may well have been satirized on stage." 1

Periphoretos may have two meanings: "he who is carried about" or "he who is bandied about," as of a person of notorious reputation, or even "passed from hand to hand," in the sense of promiscuous. To be sure, Anakreon's Artemon was also carried around in a litter, for luxury and perhaps affectation, but the thrust of the poet's invective is on his dubious moral standing. If the nickname had already been known in Athens with its second meaning, because of the Anakreontic verses, it would hardly have been used for a war hero. Although periponeros can also be translated in two opposing ways - "highly afflicted," as appropriate for a disabled person, or "very villainous," for a scoundrel-this nickname would have been more appropriate for the engineer,

${ }^{60}$ W. Gauer, "Die Ephesischen Amazonen, das Bildnis des Artemon und der samische Krieg des Perikles," in $\mathrm{H}$. Froning et al. eds., Kotinos: Festschrift für Erika Simon (Mainz 1992) 188-98. See esp. p. 189 and n. 8, where he speculates further (and improbably, to my mind) that a South Italian workshop, probably of Pythagoras, after that master's death may have specialized in reproducing masterpieces from the Greek mainland, and thus have cast works by Pheidias and Polykleitos. The main thrust of his article is, however, on the Ephesian Amazons, and only the Samian link brings about the discussion of Artemon periphoretos.

For other mentions of this Polykleitan attribution, see, e.g., A.H. Borbein, "Polyklet," GGA 234 (1982) 184-241, esp. 211, with additional references. He also cites the Amazon with the Artemon, but is against their alleged indication that Polykleitos worked briefly in and for Athens. Borbein does not include the periphoretos in his more recent discussion (supra n. 24). See also B.S. Ridgway, "Paene ad exemplum: Polykeitos' Other Works," in W.G. Moon ed., Polykleitos, the Doryphoros, and Tradition (Madison 1995) 177-99, the joke in the wordplay would have still been effective, and even the indirect allusion to the Anakre ontic Artemon could not have been missed. But would the Periklean man - in the 440 s, when so few portraits were being made-be honored with a statue by Polykleitos?

It seems to me that the explanation for Pliny's passage can be found in another of his statements. In listing the works by Myron (HN 34.57-58), Pliny mentions that the sculptor made "a monument to a cicada and a locust, as Erinna indicates in her poem." It has long been understood that Pliny was here re ferring to a tomb for a pet locust and a pet cicada set up by a girl named Myro - a name that he mis. takenly associated with Myron, perhaps through a misreading of a poem still preserved in the Greek Anthology, or through faulty note-taking. ${ }^{62}$ Given his consultation of poetry among his readings, and Anakreon's well-known Samian stay, Pliny might have conflated his information through mental association, thus erroneously ascribing to a master contemporary with Perikles' Samian war a subject that belonged purely within the poetic realm of a much earlier generation. ${ }^{63}$ Whether or not Artemon the engineer was indeed lame, Polykleitos's "Artemon periphoretos" would therefore be a Plinian phantom like Myron's cicada and locust. esp. 182. The periphoretos is not mentioned in the extensive catalogue, H. Beck et al. eds., Polyklet: Der Bildhauer der griechischen Klassik (Frankfurt 1990).

${ }^{61}$ Brown (supra n. 52) 5. He thinks that Artemon "was significantly misidentified." Anakreon's Artemon is also called poneros in the famous poem, but with a pejorative meaning.

${ }^{62}$ Anth. Lyr. Graec. 7.190. See J.J. Pollitt, The Art of Ancient Greece. Sources and Documents ${ }^{2}$ (Cambridge 1990) 49 and $n$. 9; cf. also 76 and n. 42 on Polykleitos's Artemon and the meanings of periphoretos. Pliny's list of Polykleitos's oeuvre also contains works that should be given to a different Polykleitos, and perhaps even to a Polykles: cf. Ridgway (supra n. 60) 181-82. Note also that Pliny calls Polykleitos Sikyon. ian, whereas the master was probably Argive.

63 On Pliny's technique and in general on ancient cita. tions, see the illuminating comments by J.P. Small, Wax Tablets of the Mind: Cognitive Studies of Memory and Literacy in Classical Antiquity (London 1997), esp. 188-90. 